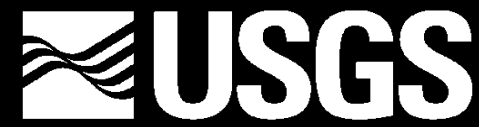

science for a changing world

U.S. DEPARTMENT OF THE INTERIOR

U.S. GEOLOGICAL SURVEY

\title{
Preliminary Potential- Field Constraints on the Geometry of the San Fernando Basin, Southern California
}

by V.E. Langenheim ${ }^{1}$, A. Griscom ${ }^{1}$, R.C. Jachens ${ }^{1}$, and T.G. Hildenbrand $^{1}$

Open-File Report 00-219

2000

This report is preliminary and has not been reviewed for conformity with U.S. Geological Survey editorial standards or with the North American Stratigraphic Code. Any use of trade, firm, or product names is for descriptive purposes only and does not imply endorsement by the U.S. Government.

U.S. DEPARTMENT OF THE INTERIOR

U.S. GEOLOGICAL SURVEY

${ }^{1}$ Menlo Park, California 


\section{TABLE OF CONTENTS}

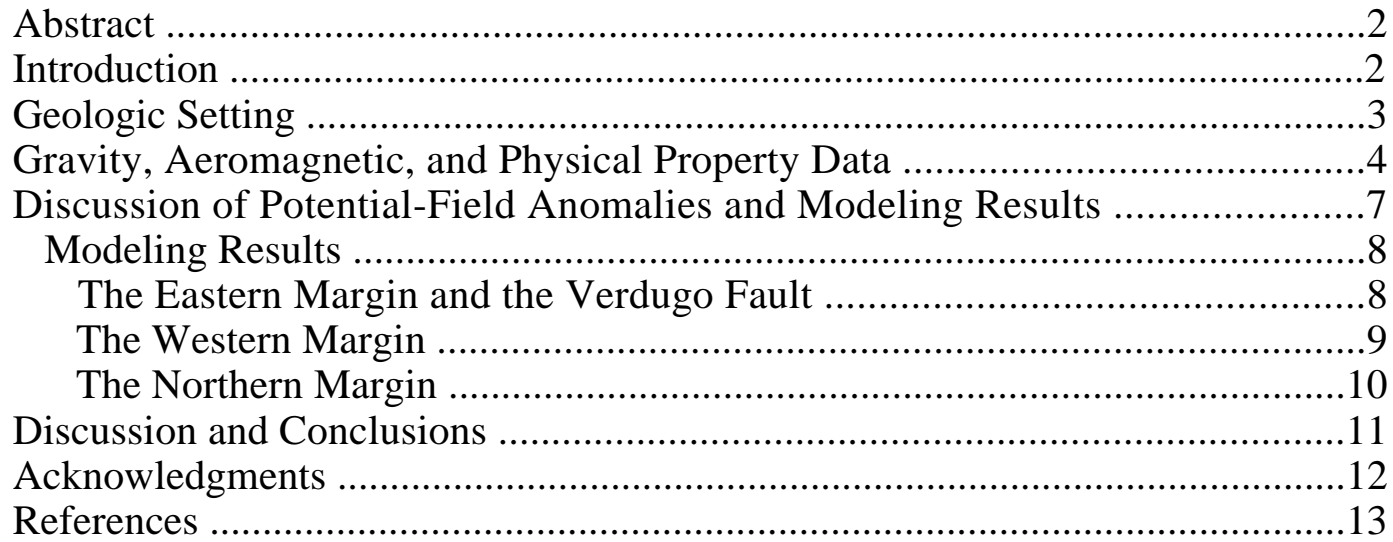

\section{TABLES}

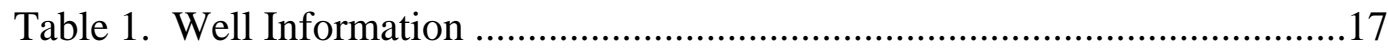

Table 2. Physical Property Data .................................................................... 18

Table 3. Additional Well Information ...............................................................19

\section{FIGURES}

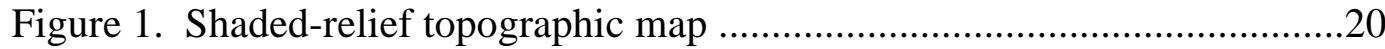

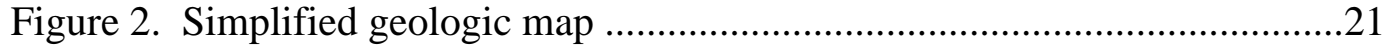

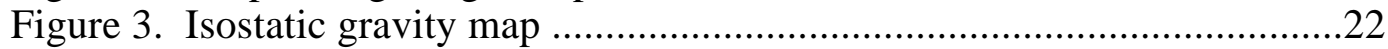

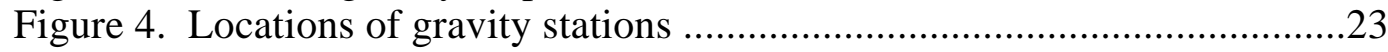

Figure 5. Densities of core samples ...........................................................24

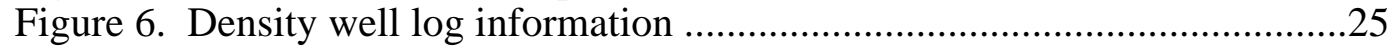

Figure 7. Densities derived from sonic velocities .......................................26

Figure 8. Gravity and aeromagnetic maps with seismicity ..........................28

Figure 9. Models across the Verdugo Fault .............................................29

Figure 10. Map of wells and model across the western margin .......................31

Figure 11. Model of Oakeshott geologic cross-section ................................33

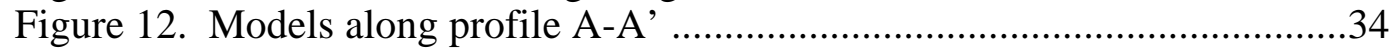

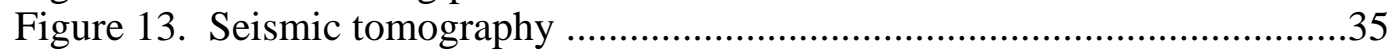

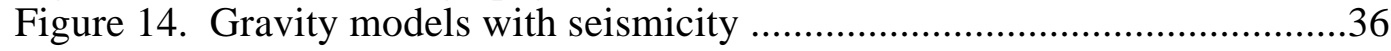

Figure 15. Structural models to explain Northridge earhquake .......................36 


\begin{abstract}
Gravity and magnetic data provide new insights on the structural underpinnings of the San Fernando Basin region, which may be important to ground motion models. Gravity data indicate that a deep basin $(>5 \mathrm{~km})$ underlies the northern part of the San Fernando Valley; this deep basin is required to explain the lowest gravity values over the Mission Hills thrust fault. Gravity modeling, constrained by well data and density information, shows that the basin may reach a thickness of $8 \mathrm{~km}$, coinciding with the upper termination of the 1994 Northridge earthquake mainshock rupture. The basin is deeper than previous estimates by 2 to $4 \mathrm{~km}$; this estimate is the result of high densities for the gravels of the Pliocene-Pleisocene Saugus Formation. The geometry of the southern margin of the deep basin is not wellconstrained by the gravity data, but may dip to the south. Recently acquired seismic data along the LARSE (Los Angeles Regional Seismic Experiment) II profile may provide constraints to determine the location and attitude of the basin edge. Gravity and aeromagnetic models across the eastern margin of the San Fernando Valley indicate that the Verdugo fault may dip to the southwest along its southern extent and therefore have a normal fault geometry whereas it clearly has a thrust fault geometry along its northern strand.
\end{abstract}

\title{
INTRODUCTION
}

The January 17, 1994 Northridge earthquake (Fig. 1) again highlighted the hazard of buried thrust faults in California. It was not the first damaging thrust-mechanism earthquake in the San Fernando Valley; it was preceded by the 1971 San Fernando earthquake. Despite the flurry of research that resulted from the 1971 earthquake (e.g., U.S. Geological Survey, 1971; Oakeshott, 1975a), the fault that produced the Northridge 1994 earthquake was not identified as a near-term seismic hazard. One tangible hint that the area might be subject to another damaging earthquake in the near future came from geodetic data, indicating relatively high strain rates for the central Transverse Ranges (Donnellan and others, 1993). Given that the region is riddled with exposed (and buried), potentially dangerous thrust faults, important components for quantifying seismic hazard include geodetic data on strain rates and information on where the greatest shaking will occur using various earthquake scenarios. The geometry of the basin, including the geometry of the bounding faults, is needed in modeling the ground motion caused by earthquakes. Wald and Graves (1998) compare the predicted ground motions from three separate 3-dimensional velocity models for southern California. The largest disparities in the response of these models are in San Fernando Valley and the deepest part of the Los Angeles basin. According to their analysis, the structure of the basin, in particular, its depth extent, is a major factor in producing the discrepancies between the velocity models. Other factors such as fault geometry, geometry 
of Quaternary fill, and uncertainties in shear wave velocities also are important. The disparity of predictions in the San Fernando Valley is not surprising, because the geometry of the San Fernando Basin is not well known. Corbato (1963) documented a significant density contrast between the basin fill and the basement rocks and thus used gravity data to infer a basin $4.5 \mathrm{~km}$ deep in the central part of the valley, south of the Mission Hills thrust fault (Fig. 2) whereas a cross section by Oakeshott (1975b) shows that the deep basin is between the San Gabriel Mountains and the Mission Hills thrust fault, with the deepest part $(6 \mathrm{~km})$ thrust beneath the San Gabriel Mountains. We present new 2 1/2 dimensional ${ }^{*}$ gravity and magnetic models to determine the basin geometry across the San Fernando Valley, using surficial geology and available density, seismic-reflection, and deep exploration well data as constraints, and compare our model to seismicity and seismic tomography results.

\section{GEOLOGIC SETTING}

The San Fernando Valley is a triangular basin (Figs.1 and 2) within the Transverse Ranges province, an area noted for its strong and relatively young deformation (Donnellan and others, 1993; Yeats and others, 1994; Wright, 1990). The Transverse Ranges province is a region of north-south shortening that lies at a high angle to the predominant northwest trend of the San Andreas fault system. Its topographic features (Figure 1) and structures trend east-west, most strikingly developed in the Ventura basin. The San Fernando Valley lies at the extreme southeastern end of the Ventura basin. The southern margin of San Fernando Valley, the Santa Monica Mountains, shares an east-west trend with the rest of the Transverse Ranges. The southern margin of the Santa Monica Mountains is marked by a system of north-dipping thrust faults, including the Malibu and Santa Monica thrust faults. The northern corner of the San Fernando basin is marked by a steep topographic front (Fig. 1) and by the north-dipping Santa Susana thrust fault (SST on Fig. 2). The Santa Susana thrust fault is part of a discontinuous thrust belt extending from the San Cayetano fault on the west to the Sierra Madre fault on the east.

Unlike the northern and southern boundaries of the San Fernando Valley, however, the eastern margin of the valley trends northwest, parallel to the San Gabriel fault (SGF), and is

\footnotetext{
* 2-1/2 dimensional modeling limits the lateral dimensions of the source bodies in and out of the plane of the profile whereas 2-D models assume the source to extend infinitely in and out of the plane of the profile.
} 
bounded by the plutonic and metamorphic rocks of the Verdugo Mountains (Figure 2). The western edge of the valley, defined by exposed Eocene and Cretaceous rocks of the Chatsworth Hills, trends northeast.

The San Fernando Valley is underlain by Miocene to Holocene sedimentary rocks. The Miocene section includes the sandstones and conglomerates of the Topanga Formation (which contains locally basalt flows) and the marine sandstones and shales of the Modelo and Towsley Formations. These rocks are overlain by the marine sandstones and mudstones of the Pliocene Fernando Formation, which grades upward and laterally into the shallow marine and nonmarine Saugus Formation. The Saugus Formation undergoes a clast change, from basement lithologies presumably derived from the San Gabriel Mountains, to locally derived clasts of Modelo and Towsley Formations (Treiman, 1986); this change in clast composition has been used to date uplift on the Santa Susana thrust fault (Levi and Yeats, 1993). Cretaceous through Eocene rocks also underlie the western part of the basin (Yerkes and Showalter, 1990), but wells in the eastern part of the valley (wells 5 and 6; Fig. 1; Table 1) show Miocene rocks on top of granite and quartz diorite. From these geologic relations, Yerkes and others (1965) proposed that Cretaceous and Paleocene rocks thicken towards the west in the Santa Monica Mountains, although Weber and others (1980) suggested that the eastern limit of Cretaceous and Paleocene rocks under western San Fernando Valley may be offset 7 to $10 \mathrm{~km}$ left laterally along concealed faults from their counterparts in the eastern Santa Monica Mountains.

According to Weber and others (1980), basement rocks exposed in the Verdugo Mountains appear to be equivalent to rocks in the San Gabriel Mountains south of the SGF. The Verdugo Mountains rocks include gneissic quartz diorite and diorite and dioritic gneiss intruded by granitic rocks and dikes. Gabbro and schist are also locally present. Basement rocks of the Santa Monica Mountains consist of the Santa Monica slate which is intruded by granitic rocks. A much smaller proportion of metamorphic inclusions occur there than in the Verdugo Mountains. Because of this difference in lithology, a major fault may separate the Santa Monica and San Gabriel Mountains terranes (Weber and others, 1980). Two possible locations for such a fault have been proposed: Yerkes and others (1965) infer a fault $5 \mathrm{~km}$ west of and paralleling the Verdugo fault (VF on Fig. 2) whereas Schnurr and Koch (1979) show a high-angle fault separating Santa Monica slate from granitic rocks along the southern edge of San Fernando Valley. 


\section{GRAVITY, AEROMAGNETIC, AND PHYSICAL PROPERTY DATA}

The isostatic gravity map of the study area (Fig. 3) is based on more than 5000 gravity measurements (Fig. 4). The sources of these data include Oliver and others (1981), Langenheim and Jachens (1996), and the Defense Mapping Agency. Most of the data west of $118^{\circ} 30^{\prime}$ west longitude and between $34^{\circ}$ and $34^{\circ} 30^{\prime}$ north latitude are from the Defense Mapping Agency. Station spacing ranges widely in the region. Mountainous areas (e.g., the San Gabriel Mountains) tend to have sparser gravity station coverage and may have only 1 station per $10 \mathrm{~km}^{2}$; basin areas generally have denser gravity station coverage, as many as 23 stations per $\mathrm{km}^{2}$ and averaging about 1 station per $\mathrm{km}^{2}$.

Gravity data were reduced using the Geodetic Reference System of 1967 (International Union of Geodesy and Geophysics, 1971) and referenced to the International Gravity Standardization Net 1971 gravity datum (Morelli, 1974, p. 18). Gravity data were reduced to complete Bouguer and isostatic residual anomalies using a reduction density of $2.67 \mathrm{~g} / \mathrm{cm}^{3}$. These data have been corrected for earth-tide, instrument drift, and free-air, Bouguer, latitude, curvature, and terrain effects. An isostatic correction using a sea-level crustal thickness of 25 $\mathrm{km}$, a crustal density of $2.67 \mathrm{~g} / \mathrm{cm}^{3}$, and a mantle-crust density contrast of $0.40 \mathrm{~g} / \mathrm{cm}^{3}$ was applied to the gravity data to remove long-wavelength crustal gravity effects due to topographic loading (Jachens and Griscom, 1985). These parameters were used because (1) they are consistent with model parameters used for isostatic corrections computed for California (Roberts and others, 1990), and (2) changing the model parameters does not significantly affect the resulting isostatic anomaly (Simpson and others, 1986).

Terrain corrections were computed to a radial distance of $167 \mathrm{~km}$ and involved a 3-part process: (1) Hayford-Bowie zones A and B with an outer radius of $68 \mathrm{~m}$ were estimated in the field with the aid of tables and charts, (2) Hayford-Bowie zones C and D with an outer radius of $590 \mathrm{~m}$ were computed by hand, and (3) terrain corrections from a distance of $0.59 \mathrm{~km}$ to $167 \mathrm{~km}$ were calculated using a digital elevation model and a procedure by Plouff (1977). Total terrain corrections for the stations on Figure 4 ranged from 0.0 to $40.3 \mathrm{mGal}$ (in the San Gabriel Mountains), averaging $2.7 \mathrm{mGal}$. Uncertainties resulting from the terrain correction range from less than $0.1 \mathrm{mGal}$ in the relatively flat areas of the San Fernando Valley and the 
Los Angeles basin to as much as $4.0 \mathrm{mGal}$ in the most rugged area of the San Gabriel Mountains.

Density information is necessary for quantitative interpretation of gravity anomalies. Corbato (1963) presented density information from four drillholes (wells 10, 14, 15, and 16; Table 1; Figure 1) in San Fernando Valley. Measurements were made on core samples from depths of 645 to $10,545 \mathrm{ft}$ (197 to $3214 \mathrm{~m}$ ). Most of the core samples are composed of the gravels of the Pleistocene-Pliocene Saugus Formation. These densities (Figure 5) are high for Pliocene sediments, especially compared to a density of $1.97 \mathrm{~g} / \mathrm{cm}^{3}$ for a Pliocene siltstone (McCulloh, 1957). Corbato also calculated the density of alluvium, based on porosity measurements of Eckis (1934). He found that the density of the alluvium varied inversely with distance from the San Gabriel and Santa Susana Mountains, from a maximum of 2.46 to a minimum of $1.97 \mathrm{~g} / \mathrm{cm}^{3}$ (average $2.26 \mathrm{~g} / \mathrm{cm}^{3}$ ). His average density for Quaternary to Miocene sedimentary rocks is $2.20 \mathrm{~g} / \mathrm{cm}^{3}$, for mid-Miocene to Cretaceous rocks is $2.47 \mathrm{~g} / \mathrm{cm}^{3}$ and for basement rocks is $2.67 \mathrm{~g} / \mathrm{cm}^{3}$ based on measurements on hand samples (McCulloh, 1957).

Another source of density information comes from sonic and density logs (Brocher and others, 1998). Brocher and others (1998) show sonic logs for wells 5, 6, 7 and 8 (Table 1) and density logs for wells 7 and 8 (Figure 6). We correlated the sonic and density logs from well 7 to determine the relationship between sonic velocity, $\mathbf{v}$, in $\mathrm{m} / \mathrm{s}$, and density, $\rho$, in $\mathrm{g} / \mathrm{cm}^{3}$, for calculating the density of the other wells. The linear regression is (where $\mathrm{R}$ is the correlation coefficient):

$$
\rho=1.3002+0.00040811 \mathbf{v} \quad R=0.643
$$

We did not use data from well 8 because of the high degree of noise in the well log data. We also determined a density-velocity relationship using well 7 and three other wells in the Los Angeles Basin (Northam Station, Ferris, and Murphy Whittier; Brocher and others, 1998). The resulting linear regression is:

$$
\rho=1.7807+0.0001668 \mathbf{v} \quad R=0.605
$$

The latter regression gives a higher density at the surface, but increases more slowly with velocity at depth. The densities based on equations 1 and 2 for wells 5 and 6 are shown in Figure 7. Densities from equation (2) are almost the same as those calculated using the velocity-density relationship of Gardner and others (1974); equation (1) predicts higher 
densities for velocities greater than $2 \mathrm{~km} / \mathrm{s}$. Regardless of the equation used and despite the wide scatter in values, in general, the densities for the upper $1000 \mathrm{~m}$ are generally between 2.0 and $2.2 \mathrm{~g} / \mathrm{cm}^{3}$. For depths greater than $1000 \mathrm{~m}$, the average density approaches $2.4 \mathrm{~g} / \mathrm{cm}^{3}$.

We also measured the densities and magnetic susceptibilities from rock samples of various basement lithologies (pre-Cenozoic metamorphic and igneous rocks) surrounding the San Fernando Valley. These results are summarized in Table 2. The average density of 165 samples is $2.71 \mathrm{~g} / \mathrm{cm}^{3}$. The Santa Monica slate is characterized by lower densities, averaging $2.66 \mathrm{~g} / \mathrm{cm}^{3}(\mathrm{~N}=9)$, and are essentially non-magnetic. Plutonic rocks that intrude the slate are also essentially non-magnetic as is a sample from well 6 (Table 1). The average density of the exposed plutonic rocks may be too low $\left(2.59 \mathrm{~g} / \mathrm{cm}^{3}\right)$ because of sampling bias of very weathered samples; the core sample from well 6 gives a higher density of $2.65 \mathrm{~g} / \mathrm{cm}^{3}$. Crystalline basement rocks exposed in the Verdugo and San Gabriel Mountains are generally magnetic and have higher densities. The average density for rocks in the Verdugo Mountains is $2.71 \mathrm{~g} / \mathrm{cm}^{3}(\mathrm{~N}=32)$, for those rocks in the San Gabriel Mountains south of the SGF, $2.70 \mathrm{~g} / \mathrm{cm}^{3}(\mathrm{~N}=23)$ and rocks exposed north of the SGF, 2.72 $\mathrm{g} / \mathrm{cm}^{3}(\mathrm{~N}=98)$.

High-resolution aeromagnetic data were collected over the region in 1995 (U.S. Geological Survey, 1996) and added to existing data over the Ventura basin (U.S. Geological Survey, 1980). Most of the new data were flown along N-S trending flightlines spaced $800 \mathrm{~m}$ apart with an average terrain clearance of $550 \mathrm{~m}$.

\section{DISCUSSION OF POTENTIAL-FIELD ANOMALIES AND MODELING RESULTS}

The San Fernando basin is at the eastern end of a large ( $60 \mathrm{mGal})$, east-west-trending gravity low over the Ventura basin (Fig. 3). The Ventura Basin gravity low curves to the southeast without interruption into the San Fernando gravity low. Gravity modeling shows that the Ventura gravity low is caused predominantly by Pliocene and younger deposits and that the basin may be as deep as $15 \mathrm{~km}$ (Jachens and Griscom, 1985). The gravity data are consistent with the cross sections of Nagle and Parker (1971) and Yeats and others (1994) 
that indicate the Ventura basin is bounded by north- and south-dipping thrust faults on the north and south sides, respectively.

The 40-mGal gravity low over the San Fernando Valley (Fig. 3) suggests that the underlying basin is asymmetric. The lowest gravity values occur over the Mission Hills thrust fault in the northern part of the valley (MHT on Fig. 2). A thrust fault bounding the northern margin of the basin is clearly expressed by low gravity values $(-20 \mathrm{mGal})$ over exposed basement rocks (Fig. 3). This observation suggests that low-density material is thrust beneath the crystalline basement rocks and is consistent with geologic mapping (Oakeshott, 1975b). Another place where gravity data support a thrust fault geometry is along the northern edge of the Los Angeles basin. Gravity data indicate a north-dipping attitude for the Santa Monica thrust fault because the mapped trace of the fault lies at the base of the gravity gradient (Fig. 3).

The gentle gravity gradient south of the Mission Hills thrust fault is interrupted abruptly at its western end by a northeast-trending gravity gradient that corresponds in part to the northeast-trending Chatsworth Reservoir fault (CRF on Fig. 2). The steepness of the gravity gradient suggests that this northeast-trending boundary is steeply dipping. This fault may be a high-angle tear or normal fault that juxtaposes the Ventura basin thrust fault system with the thrust fault system underlying the San Fernando Valley. Shields (1978) shows a dip of $62^{0}$ to the southeast for the Chatsworth Reservoir fault based on two oil exploration boreholes. The gravity gradient deviates from the southern half of the fault trace (where the mapped trace begins to strike more easterly), suggesting that the basin edge is approximately linear with a strike of $\mathrm{N} 45^{\circ} \mathrm{E}$.

The northeast-trending gravity gradient (Fig. 8a) corresponds to a northeast trend in the 1971 San Fernando aftershocks called the Chatsworth trend (Hanks and others, 1971) and coincides approximately with the southeast edge of a magnetic block ("C" on Fig. 8b). These aftershocks were southwest of the mainshock and were characterized by left-lateral focal mechanisms. Whitcomb (1971) suggested that this seismicity represented motion of the lower thrust block against a block to the northwest along a left-lateral strike-slip fault. The aftershocks of the 1994 Northridge earthquake also appear to follow the northeasttrending gravity gradient as it bends into alignment with the east-west-trending gravity gradients associated with the Ventura basin margins. However, Hauksson and others (1995) did not find evidence of reactivation of the Chatsworth trend in the 1994 Northridge 
aftershocks. They instead suggested that the San Fernando lateral ramp in the Santa Susana thrust fault influences the spatial distribution of aftershocks in the region. This lateral ramp is on trend with the Chatsworth Reservoir fault and coincides with a change in trend from eastwest to northeast-southwest along the Santa Susana thrust fault (Fig. 2). The base of the aftershock distribution west of the ramp is $3-5 \mathrm{~km}$ higher than that east of the ramp (Hauksson and others, 1995).

The magnetic field over the San Fernando Valley is characterized by low-amplitude, shortand long-wavelength anomalies and suggests that the basement rocks of the San Fernando Valley are weakly magnetic (Fig. 8b). Some of the short-wavelength anomalies have sources within the basin fill, possibly related to the volcanic rocks in the Topanga Formation, gravels of the Saugus Formation derived from the magnetic crystalline rocks exposed in the San Gabriel Mountains, or an unknown source near the top of the Cretaceous sedimentary sequence, which produces subtle, northeast-trending anomalies west of the Chatsworth Reservoir fault (Fig. 8b).

The eastern margin of the San Fernando basin appears to be bounded by a high-angle fault as indicated by steep gravity and aeromagnetic gradients. The basin is bounded on the east by the Verdugo fault, which forms the southwestern margin of a highly-magnetic block. The magnetic data confirm that Verdugo Mountain rocks extend east to the San Gabriel fault, as suggested by Weber and others (1980). The magnetic data do not indicate a major fault separating the Santa Monica and San Gabriel terranes along the southern edge of San Fernando Valley as proposed by Schnurr and Koch (1979), but do suggest a major magnetic terrane boundary at or near the Verdugo fault (see below).

\section{Modeling Results}

We created several gravity and aeromagnetic models across the San Fernando Valley crossing the major structures bounding the basin. First we discuss the models across the eastern and western margins of the basin, followed by models of the northern margin.

The Eastern Margin and the Verdugo Fault

Two models cross the eastern margin of the basin, where the major bounding structure is the Verdugo fault. Both the gravity and magnetic data suggest that the Verdugo fault changes character along strike. The northwest-trending gravity gradient associated with the 
fault is interrupted by a north-south-striking gradient near point X (Fig. 8a). Northwest of this point, the inferred fault trace lies near the bottom of the northwest-trending gradient; implying a thrust geometry; southeast of $\mathrm{X}$, the fault trace is near the top of the gradient, suggesting a normal fault geometry. Southeast of point X, aeromagnetic data indicate a 5-kmwide gradient southwest of the fault; this gradient disappears northwest of point X.

The model along profile $\mathrm{V}-\mathrm{V}$ ' addresses the geometry of the Verdugo fault southeast of point X. Modeling across the mostly concealed Verdugo fault suggests that it dips steeply $\left(>60^{\circ}\right)$ to the southwest (Fig. 9a) and thus may not be a thrust fault as shown on a schematic cross section by Weber and others (1980); their northeast-dipping attitude for the Verdugo fault is based on foliation in the crystalline basement rocks. Weber and others (1980) showed a fault with alluvium on crystalline bedrock with a southwest dip, but they argued that it is a minor fault and not indicative of the geometry of the major basin-bounding structure. An alternative explanation for the structure shown in $\mathrm{V}-\mathrm{V}^{\prime}$ is that the apparent normal geometry is the result of a stack of several thrust faults stepping southwest away from the mountain front. Detailed gravity data could detect whether the gradient is the result of one fault of normal geometry or several faults of thrust geometry.

Northwest of point X, along profile T-T' (Fig. 2), Tsustumi and Yeats (1999) showed the Verdugo fault as a northeast-dipping thrust fault. They furthermore suggested that the thrust fault is a reactivation of a Miocene normal fault, based on a thicker Miocene section on the upthrown block. We modeled their profile T-T' (Fig. 9b), but as a straight section (see dashed line in Fig. 2) because the gravity and aeromagnetic data suggest that the Verdugo fault may not extend as far northwest as the bend in profile T-T' (Fig. 8). We used the same well constraints that Tsutsumi and Yeats show for their cross section. With these constraints, a higher density is needed for the Saugus gravels on the northeastern end of the model. We also model a magnetic source (volcanic rocks) within the Topanga Formation, in the vicinity of well 2A (Tsutsumi and Yeats, 1999), to account for the 40-nT aeromagnetic anomaly west of the Pacoima Hills (another possible source for this anomaly is a source within the basement; the gradients of the anomaly point to a shallow source, but are complicated by three-dimensional effects of the positive anomaly over the Pacoima Hills). The model indicates a thrust geometry for the fault bounding the Pacoima Hills. This area is very three-dimensional. The cross section of Tsutsumi and Yeats (1999) is not a straight line, but jumps to northwest of the Pacoima Hills; thus, the fault that Tsutsumi and Yeats 
(1999) call the Verdugo fault may actually be an east-west-trending thrust fault on strike with and possibly related to the Mission Hills thrust fault.

\section{The Western Margin}

The western margin of the valley is not characterized by any outcrops of crystalline basement. No wells penetrate crystalline basement; thus, its lithology and affinity are unknown. However, the Simi Hills are composed of the oldest sedimentary rocks exposed in the area, the late Cretaceous marine sandstones and conglomerates of the Chatsworth Formation (Colburn and others, 1981). The exposed thickness of these rocks is about $1.4 \mathrm{~km}$ (Sage, 1971); the base of the sequence is not exposed or reached by wells (Shields, 1977). Although seismic-reflection profiles (Fig. 10a) do not clearly image the crystalline basement in the valley (D. Okaya, oral commun., 1999), we used these sections to provide minimum thicknesses of the Miocene/Eocene sedimentary sequence for profile C-C' (Fig. 10b).

An interesting result of the modeling is the presence of a magnetic bed near the top of the Cretaceous strata that produces a linear, 20-nT aeromagnetic anomaly over the Simi Hills. The wavelength of the anomaly and the strike of the anomaly (parallel to the strike of the strata) indicate that it should lie near or at the surface. These source rocks may be responsible for short-wavelength anomalies within San Fernando Valley and thus could serve as a marker for structures cutting the sedimentary section.

\section{The Northern Margin}

Figure 11 shows a gravity and magnetic model across the geologic cross section by Oakeshott (1975b; O-O' on Figure 2). His basin is asymmetric, with the deepest part of the basin thrust beneath crystalline basement rocks northeast of the Santa Susana thrust fault. The calculated gravity curve using Oakeshott's geometry does not match the observed data well southwest of the Santa Susana thrust fault. The basin must be deeper on the southwestern part of the profile to account for the mismatch. Oakeshott constructed this cross section before the discovery of the Pacoima oil field; borehole data (e.g., well 11) indicate basin depths of $3 \mathrm{~km}$ and greater at the southwest end of O-O'. This model clearly illustrates how, to a first order, geologic cross sections across the San Fernando Valley can benefit from incorporating gravity data. 
Profile A-A' bisects the San Fernando Valley along a north-south line (Fig. 1). Although the orientation is not ideal for the northern end of the profile where it crosses the Soledad basin, it maximizes the available deep borehole control and attempts to avoid edge effects from the three-dimensional aspect of the San Fernando basin. The model is 2-1/2dimensional. The observed points are gravity stations within $1 \mathrm{~km}$ of the profile.

The gravity model A (Fig. 12) demonstrates that basin sediments may exceed $5 \mathrm{~km}$ in thickness in the northern part of the basin to account for the gravity low. The inferred basin is significantly thicker than that estimated by Corbato (1963) or Oakeshott (1975b). This greater depth extent is forced by the use of higher densities in the Pliocene sedimentary rocks as constrained by core density measurements presented in Corbato (1963; Fig. 5). Although the core density measurements may be biased towards higher densities, densities are higher closer to the range front (as high as $2.47 \mathrm{~g} / \mathrm{cm}^{3}$ ) as indicated by porosity measurements of alluvium (Corbato, 1963). The uniform decrease in gravity values from the Santa Monica Mountains across the San Fernando basin cannot be modelled with a gently-north dipping Miocene section unless one assumes that the Miocene sedimentary rocks have densities of $2.00 \mathrm{~g} / \mathrm{cm}^{3}$ or less. As we have shown in Figure 7, a more representative density for the Miocene sedimentary rocks is between 2.10 and $2.30 \mathrm{~g} / \mathrm{cm}^{3}$.

Our models (Fig. 12) solve the Miocene density enigma by extending a lower-density basement source to depths of $10 \mathrm{~km}$. This lower-density basement could be composed predominantly of Jurassic Santa Monica Slate which is exposed near profile A-A' where it crosses the Santa Monica Mountains. More likely, it could consist of granitic intrusions, similar to the rocks found in drill holes 5 and 6 in the basin. Model B shows that the location and attitude of the southern margin of the deep basin are not well constrained.

Although not the focus of the paper, geometries of faults and basins beyond San Fernando Valley are shown in our models. At the southern end of profile A-A', our models confirm a north-dipping attitude for the Santa Monica fault. On the northern end of the profile, the Soledad basin is nearly $4 \mathrm{~km}$ thick, consistent with estimates of the aggregate thickness of the Tertiary section of $4300 \mathrm{~m}$ (14,000 ft; Oakeshott, 1975b).

\section{DISCUSSION AND CONCLUSIONS}

The gravity model along A-A' is, to first order, consistent with the tomographic results of Hauksson and Haase (1997; Fig. 13). Their results indicate velocities less than $6 \mathrm{~km} / \mathrm{s}$ to 
depths of 8 to $9 \mathrm{~km}$ in the area of our deep basin. Mori and others (1995) also show slower velocities under the San Fernando Valley at depths of 5 and $10 \mathrm{~km}$, although neither of these models have particularly good resolution at these depths. The tomographic data (Hauksson and Haase, 1997) hint of a southern dip for the southern boundary of the deep basin; however, one must bear in mind that the tomography is based on a $10-\mathrm{km}$ horizontal grid and will not produce fine detail. For example, the sliver of basement rocks south of the San Gabriel fault (between 40-45 km on Fig. 13) is not characterized by high velocities in the tomographic model because it is too thin and/or because of fracturing. The gravity data (and model) do not indicate a shallow, high-density body at about km 16, suggesting that the high-velocity anomaly at $1 \mathrm{~km}$ depth is an artifact (Hauksson and Haase, 1997). Other possible artifacts are caused by ray-tracing and are highlighted by arrows.

Figure 14 shows the aftershock seismicity from the 1994 and 1971 earthquakes plotted on the gravity models (from within $2 \mathrm{~km}$ of the profile). The main south-dipping rupture defined by seismicity does not coincide with the edge of the deep basin in either model A and B, but this contact is not well constrained. It is possible that the edge of the basin does coincide with the 1994 Northridge mainshock rupture. In both models, the bottom of the basin coincides with the upper termination of the rupture at roughly $7-8 \mathrm{~km}$ determined by Hauksson and others (1995), roughly the $6 \mathrm{~km} / \mathrm{s}$ contour on Figure 13. Hauksson and others (1995) interpret the diffuse cloud of seismicity at $7 \mathrm{~km}$ as deformation in an anticlinal fold; however, another possible explanation is that the cloud of seismicity and the upper end of the rupture are controlled by the base of the deep basin.

Two interpretations of the mainshock faulting have been suggested (Fig. 15). Namson and Davis (1994) proposed a model with the mainshock fault as a south-dipping back-thrust to the Elysian Park thrust fault beneath Los Angeles. Yeats and Huftile (1995), alternatively, attribute the mainshock fault to an extension of the Oak Ridge fault (Fig. 2) eastwards beneath San Fernando Valley. Yeats and Huftile (1995) use gravity data (Langenheim and others, 1994) to support their interpretation; however, our modeled profile, though provocative, does not prove their hypothesis. The gravity models support both interpretations.

Our model of the Santa Susana fault is consistent with geologic cross sections by Huftile and Yeats (1996) drawn at Aliso Canyon (5 km west of well 16; Fig. 1). The geologic cross sections suggest highly constrained dips of about $53^{0}$ to $60^{0} \mathrm{NE}$ for the Santa Susana fault, 
with the leading edge flattening to $10^{\circ}$ within $1 \mathrm{~km}$ of the surface. Our modeled geometry for the Santa Susana fault shows that the fault may dip about $15^{\circ}$ in upper $2 \mathrm{~km}$, steepening to $70^{\circ}$ as it intersects the San Gabriel fault. The deep basin projects beneath the San Gabriel fault.

In conclusion, gravity data indicate that a deep basin underlies the northern part of the San Fernando Valley. Gravity modeling, constrained by well data and density information, shows the basin may be as deep as $8 \mathrm{~km}$, coinciding with the upper termination of the 1994 Northridge mainshock rupture. The depth extent of the basin is highly dependent on the assumption of high densities for the Pliocene gravels in the northern part of the valley. The southern margin of the deep basin is not well constrained, but may dip to the south. Recently acquired seismic data (LARSE II) may provide constraints that help determine the location and attitude of the basin edge.

Gravity and magnetic models across the Verdugo fault show that the geometry of the fault appears to vary along strike and that the fault along its southern extent may dip to the southwest and therefore has a normal fault geometry, in contrast to the thrust fault geometry clearly seen along its northern extent. An alternative explanation for the apparent normal geometry may be a series of thrust faults that step out from the mountain front.

\section{ACKNOWLEDGEMENTS}

We would like to thank Tom Brocher and Bob Yerkes (U.S. Geological Survey, Menlo Park, CA) for their reviews. We also thank Dave Okaya (University of Southern California) for access to the seismic-reflection profiles in the San Fernando Valley and Tom Wright for thoughtful discussions of the regional geology.

\section{REFERENCES}

Brocher, T.M., Ruebel, A.L., Wright, T.L., and Okaya, D.A., 1998, Compilation of 20 sonic and density logs from 12 oil test wells along LARSE lines 1 and 2, Los Angeles region, California: U.S. Geological Survey Open-File Report 98-366, 53 p.

Colburn, I.P., Saul, L.E.R., and Almgren, A.A., 1981, The Chatsworth Formation: a new formation name for the Upper Cretaceous strata of the Simi Hills, California in Link, M.J., Squires, R.L., and Colburn, I.P. eds., Simi Hills Cretaceous Turbidites, Southern 
California: Society of Economic Paleontologists and Mineralogists Field Trip Volume and Guide Book, p. 9-16.

Corbato, C.E., 1963, Bouguer gravity anomalies of the San Fernando Valley, California: University of California Special Publication 46, no. 1, p. 1-32.

Donnellan, A., Hager, B.H., King, R.W., and Herring, T.A., 1993, Geodetic measurement of deformation in the Ventura basin, southern California: Journal of Geophysical Research, v. 98 , p. 21727-739.

Eckis, R., 1934, South coast basin investigations--geology and groundwater storage capacity of valley fill: California Divison of Water Resources Bulletin 45, 279 p.

Gardner, G.H., Gardner, L.W., and Gregory, A.R., 1974, Formation velocity and density: the diagnostic basis for stratigraphic traps: Geophysics, v. 39, p. 770-780.

Hanks, T.C., Jordan, T.H., and Minster, J.B., 1971, Precise locations of aftershocks of the San Fernando earthquake 2300 (GMT) February 10-1700 February 11, 1971 in San Fernando, California Earthquake of February 9, 1971: U.S. Geological Survey Professional Paper 733, p. 21-23.

Hauksson, E., Jones, L.M., and Hutton, K., 1995, The 1994 Northridge earthquake sequence in California: seismological and tectonic aspects: Journal of Geophysical Research, v. 100, no. B7, 12335-355.

Hauksson, E., and Haase, J.S., 1997, Three-dimensional $\mathrm{V}_{\mathrm{p}}$ and $\mathrm{V}_{\mathrm{p}} / \mathrm{V}_{\mathrm{s}}$ velocity models of the Los Angeles basin and central Transverse Ranges, California: Journal of Geophysical Research, v. 102, no. B3, p. 5423-5453.

Huftile, G.J., and Yeats, R.S., 1996, Deformation rates across the Placerita (Northridge $\mathrm{Mw}=6.7$ aftershock zone) and Hopper Canyon segments of the western Transverse Ranges deformation belt: Bulletin of Seismological Society of America, v. 86, no. 1B, p. S3-S18.

International Union of Geodesy and Geophysics, 1971, Geodetic Reference System 1967: International Association of Geodesy Special Publication no. 3, 116 p.

Jachens, R.C., and Griscom, Andrew, 1985, An isostatic residual gravity map of California-A residual map for interpretation of anomalies from intracrustal sources in Hinze, W.J., ed., The Utility of Regional Gravity and Magnetic Maps: Society of Exploration Geophysicists, Tulsa, Oklahoma, p. 347-360.

Jennings, C.W., 1994, Fault activity map of California and adjacent areas: California Division of Mines and Geology California Geologic Data Map 6, scale 1:750,000.

Langenheim, V.E., Griscom, Andrew, and Jachens, R.C., 1994, Gravity and magnetic data help image the regional tectonic setting of the 1994 Northridge earthquake in Proceedings of the 89th Annual Meeting of the Seismological Society of America, Program for Northridge abstracts: Seismological Research Letters, v. 65, no. 3/4, p. 249. 
Langenheim, V.E., and Jachens, R.C., 1996, Gravity data collected along the Los Angeles Regional Experiment (LARSE) and preliminary model of regional density variation in basement rocks, southern California: U.S. Geological Survey Open-File Report 96-682.

Levi, S., and Yeats, R.S., 1993, Paleomagnetic constraints on the initiation of uplift on the Santa Susana fault, western Transverse Ranges, California: Tectonics, v. 12, p. 688-702.

McCulloh, T.H., 1957, Simple Bouguer gravity and generalized geologic map of the northwestern part of the Los Angeles basin, California: U.S. Geological Survey Geophysical Investigations Map GP-149.

Morelli, C.(Ed.), 1974, The International Gravity Standardization Net, 1971: International Association of Geodesy Special Publication no. 4, 194 p.

Mori, J., Wald, D.J., and Wesson, R.L., 1995, Overlapping fault planes of the 1971 San Fernando and 1994 Northridge, California earthquakes: Geophysical Research Letters, v. 22, no. 9, p. 1033-1036.

Nagle, H.E., and Parker, E.S.,1971, Future oil and gas potential of onshore Ventura basin, California in Cram, I.H., editor, Future Petroleum Provinces of the United States--Their Geology and Potential: American Association of Petroleum Geologists Memoir 15, p. 254-297.

Namson, T.L., and Davis, J.S., 1994, A balanced cross-section of the 1994 Northridge earthquake, southern California: Nature, vol. 372, p. 167-169.

Oakeshott, G.B., ed., 1975a, San Fernando, California, Earthquake of 9 February 1971: California Division of Mines and Geology Bulletin 196, 463 p.

Oakeshott, G.B., 1975b, Geology of the epicentral area in Oakeshott, G.B., ed., San Fernando, California, Earthquake of 9 February 1971: California Division of Mines and Geology Bulletin 196, p. 19-30.

Oliver, H.W., Chapman, R.H., Biehler, S.H., Robbins, S.L., Hanna, W.F., Griscom, Andrew, Beyer, L.A., and Silver, E.A., 1981, Gravity map of California and its continental margin: California Division of Mines and Geology, Geologic Data Map No. 3, scale 1:750,000.

Plouff, Donald, 1977, Preliminary documentation for a FORTRAN program to compute gravity terrain corrections based on topography digitized on a geographic grid: U.S. Geological Survey Open-File Report 77-535, 45 p.

Roberts, C.W., Jachens, R.C., and Oliver, H.W., 1990, Isostatic residual gravity map of California and offshore southern California: California Division of Mines and Geology, Geologic Data Map No. 7, scale 1:750,000.

Sage, O.G., Jr., 1971, Geology of the eastern portion of the "Chico" Formation, Simi Hills, California: Master's Thesis, University of California, Santa Barbara. 
Shields, K.E., 1977, Structure of the northwestern margin of the San Fernando Valley, Los Angeles County, California: Master's Thesis, Ohio University, Athens.

Shields, K.E., 1978, Faults along the northwestern margin of the San Fernando Valley, Los Angeles county, California in Lamar, D.L., ed., Geologic guide and engineering case histories Los Angeles Metropolitan area: Association of Engineering Geologists First Annual California section conference, p. 44-52.

Schnurr, P.E., and Koch, C.E., 1979, Pacoima field in Pacific Section American Association of Petroleum Geologists field summaries: Pacific Petroleum Geologists Newsletter Winter 1979-80, v. 34, no. 4, p. 4-5.

Simpson, R.W., Jachens, R.C., Blakely, R.J., and Saltus, R.W., 1986, A new isostatic gravity map of the conterminous United States with a discussion on the significance of isostatic residual anomalies: Journal of Geophysical Research, v. 91, p. 8348-8372.

Treiman, J.H., 1986, Geological hazards in the west half of the Newhall quadrangle, Los Angeles County, California: California Division of Mines and Geology Open-File Report 86-6.

Tsutumi, Hiroyuki, and Yeats, R.S., 1999, Tectonic setting of the 1971 and 1994 Northridge earthquakes in the San Fernando Valley, California: Bulletin of the Seismological Society of America, v. 89, no. 5, p. 1232-1249.

U.S. Geological Survey, 1971, The San Fernando, California earthquake of February 9, 1971: U.S. Geological Survey Professional Paper 733, 254 p.

U.S. Geological Survey, 1980, Aeromagnetic map of the Ventura Basin, Ventura and Los Angeles Counties, California: U.S. Geological Survey Open-File Report 80-64, scale $1: 62,500$.

U.S. Geological Survey, 1996, Aeromagnetic map of parts of the Los Angeles, San Bernardino, Bakersfield, Long Beach, and Santa Ana $1^{\circ}$ by $2^{\circ}$ quadrangles, California: U.S. Geological Survey Open-File Report 96-550, scale 1:250,000.

Wald, D.J., and Graves, R.W., 1998, The seismic response of the Los Angeles basin, California: Bulletin of the Seismological Society of America, v. 88, no. 2, p. 337-356.

Weber, F.H., Jr., Bennett, J.H., Chapman, R.H., Chase, G.W., and Saul, R.B., 1980, Earthquake hazards associated with the Verdugo-Eagle Rock and Benedict Canyon fault zones, Los Angeles county, California: U.S. Geological Survey Open-File Report 81-296, $116 \mathrm{p}$.

Whitcomb, J.H., 1971, Fault-plane solutions of the February 9, 1971, San Fernando earthquake and some aftershocks: U.S. Geological Survey Professional Paper 733, p. 3032.

Wright, T.L., 1990, Structural geology and tectonic evolution of the Los Angeles basin, California in Biddle, K.T., ed., Active Tectonic Basins: AAPG Memoir 52, p. 35-134. 
Yeats, R.S., and Huftile, G.J., 1995, The Oak Ridge fault system and the 1994 Northridge earthquake: Nature, v. 373, p. 418-420.

Yeats, R.S., Huftile, G.J., and Stitt, L.T., 1994, Late Cenozoic tectonics of the East Ventura basin, Transverse Ranges, California: American Association of Petroleum Geologists Bulletin, v. 78, p. 1040-1078.

Yerkes, R.F., and Showalter, P.K., 1990, Exploratory wells drilled in the Los Angeles 1:100,000-scale quadrangle, California: U.S. Geological Survey Open-File Report 90-627, 47 p., 1 plate.

Yerkes, R.F., McCulloh, T.H., Schoelhamer, J.E., and Vedder, J.G., 1965, Geology of Los Angeles basin, California--an introduction: U.S. Geological Survey Professional Paper $420-\mathrm{A}, 57 \mathrm{p}$. 
Table 1. Selected wells in area of modeled transects.

\begin{tabular}{|c|c|c|c|c|c|}
\hline $\begin{array}{l}\text { Figure } \\
\text { ID }\end{array}$ & $\begin{array}{l}\text { Well } \\
\text { Name }\end{array}$ & $\begin{array}{l}\text { Total } \\
\text { Depth } \\
\text { (ft) }\end{array}$ & $\begin{array}{l}\text { Lithology } \\
\text { at Bottom* }\end{array}$ & $\begin{array}{l}\text { Township/ } \\
\text { Range/Section }\end{array}$ & $\begin{array}{r}\text { Well } \\
\text { ID } \\
\end{array}$ \\
\hline 1 & Standard Oil Duff CoreHole 1 & 11209 & Miocene & $1 \mathrm{~S} / 15 \mathrm{~W} / 34$ & 2055 \\
\hline 2 & $\begin{array}{l}\text { Argo Petroleum Corp Argo- } \\
\text { Aladdin } 179-1\end{array}$ & 12085 & $\begin{array}{l}\text { Santa Monica fault, } \\
\text { 7940; Upper Miocene }\end{array}$ & $1 \mathrm{~S} / 15 \mathrm{~W} / 28$ & 2192 \\
\hline 3 & $\begin{array}{l}\text { Hudson Gas \& Oil Los Angeles } \\
\text { Country Club } 3\end{array}$ & 5515 & Slate 4600 & $1 \mathrm{~S} / 15 \mathrm{~W} / 23$ & 0099 \\
\hline 4 & $\begin{array}{l}\text { Hudson Gas \& Oil Los Angeles } \\
\text { Country Club Core Hole } 1\end{array}$ & 1990 & Slate 1900 & $1 \mathrm{~S} / 15 \mathrm{~W} / 14$ & 0545 \\
\hline 5 & Chevron Hazeltine 1 & 3823 & granite 3785 & $1 \mathrm{~N} / 15 \mathrm{~W} / 14$ & 0596 \\
\hline 6 & Chevron Leadwell 1 & 5066 & quartz diorite 4840 & $1 \mathrm{~N} / 15 \mathrm{~W} / 03$ & 0597 \\
\hline 7 & Chevron Frieda J. Clark 1 & 7323 & Miocene & $2 \mathrm{~N} / 16 \mathrm{~W} / 25$ & 2101 \\
\hline 8 & Chevron Burnet Core Hole 1 & 10227 & Miocene & $2 \mathrm{~N} / 15 \mathrm{~W} / 16$ & \\
\hline 9 & Chevron University 1 & 5938 & Miocene 3920 & $2 \mathrm{~N} / 15 \mathrm{~W} / 15$ & 0600 \\
\hline 10 & Chevron Woo 1 & 9739 & Middle Miocene & $2 \mathrm{~N} / 15 \mathrm{~W} / 19$ & 0600 \\
\hline 11 & $\begin{array}{l}\text { Occidental Petroleum Pacoima } \\
\text { EH } 1\end{array}$ & 9291 & Miocene & $2 \mathrm{~N} / 15 \mathrm{~W} / 10$ & 2051 \\
\hline 12 & Chevron Rinaldi 1 & 4725 & Middle Mohnian & $2 \mathrm{~N} / 15 \mathrm{~W} / 4$ & 0633 \\
\hline 13 & Shell Western Mission Core Hole 2 & 5687 & Mohnian & $2 \mathrm{~N} / 15 \mathrm{~W} / 4$ & 0589 \\
\hline 14 & Gulf Oil Corp. Carey 1 & 10136 & Upper Miocene & $2 \mathrm{~N} / 15 \mathrm{~W} / 15$ & \\
\hline 15 & $\begin{array}{l}\text { Sun Exploration } \\
\text { Stetson-Sombrero }\end{array}$ & 12027 & Pliocene & $3 \mathrm{~N} / 15 \mathrm{~W} / 21$ & 0603 \\
\hline 16 & ARCO T.I.\&T. 1 & 8207 & Pliocene & $3 \mathrm{~N} / 15 \mathrm{~W} / 19$ & 0518 \\
\hline 17 & $\begin{array}{l}\text { Rothschild Oil Wickham- } \\
\text { Ferrier } 1\end{array}$ & 1648 & granite 1114 & $4 \mathrm{~N} / 15 \mathrm{~W} / 32$ & 0581 \\
\hline 18 & Enterprise Oil Puckett 1 & 3992 & Miocene & $5 \mathrm{~N} / 15 \mathrm{~W} / 33$ & 0538 \\
\hline 19 & $\begin{array}{l}\text { C.R. Pohl \& Associates } \\
\text { Pohl-Green } 1\end{array}$ & 2331 & schist 2298 & $5 \mathrm{~N} / 15 \mathrm{~W} / 29$ & 0577 \\
\hline \multicolumn{6}{|c|}{ OTHER WELLS not shown in Figure 1.} \\
\hline & Standard Oil Ferris 1 & 12182 & granite 12073 & $1 \mathrm{~S} / 11 \mathrm{~W} / 21$ & 0596 \\
\hline & Chevron Murphy Whittier 304 & 14213 & Sespe 14092 & $2 \mathrm{~S} / 11 \mathrm{~W} / 26$ & 2365 \\
\hline & $\begin{array}{l}\text { Standard Oil Northam Station } \\
\text { Core } 1\end{array}$ & 11500 & Topanga 11180 & $3 \mathrm{~S} / 11 \mathrm{~W} / 27$ & 2043 \\
\hline
\end{tabular}

*Sources of stratigraphy are Brocher and others (1998) and Yerkes and Showalter (1990). 
Table 2. Summary of physical properties of basement rocks

\begin{tabular}{|c|c|c|c|c|c|}
\hline Crystalline rocks & $\begin{array}{l}\text { Densi } \\
(\mathrm{g} / \mathrm{cm}\end{array}$ & & $\begin{array}{l}\text { Magnetic su } \\
\left(10^{-3} \mathrm{cg}\right.\end{array}$ & $\begin{array}{l}\text { ceptibil } \\
\text { units) }\end{array}$ & \\
\hline All & $2.71+/-0.10$ & $\mathrm{~N}=165$ & $0.64+/-1.01$ & $\mathrm{~N}=77$ & \\
\hline Verdugo & $2.71+/-0.10$ & $\mathrm{~N}=32$ & $0.81+/-0.64$ & $\mathrm{~N}=27$ & \\
\hline San Gabriel (South of SGF) & $2.70+/-0.08$ & $\mathrm{~N}=23$ & $0.68+/-1.02$ & $\mathrm{~N}=15$ & \\
\hline San Gabriel (North of SGF) & $2.72+/-0.10$ & $\mathrm{~N}=98$ & $0.72+/-1.42$ & $\mathrm{~N}=25$ & \\
\hline Santa Monica Slate & $2.66+$ & $/-0.06 \quad \mathrm{~N}=$ & $9 \quad 0.00$ & $+/-0.01$ & $\mathrm{~N}=$ \\
\hline Santa Monica plutonic rocks & $2.59 *+/-0.17$ & $\mathrm{~N}=3$ & $0.01+/-0.01$ & $\mathrm{~N}=3$ & \\
\hline Leadwell Well granodiorite? & 2.65 & $\mathrm{~N}=1$ & 0.01 & & \\
\hline
\end{tabular}


Table 3. Additional wells shown in Figure 10b.

\begin{tabular}{lllll}
$\begin{array}{l}\text { Well } \\
\text { ID }\end{array}$ & \multicolumn{1}{c}{$\begin{array}{c}\text { Well } \\
\text { Name }\end{array}$} & $\begin{array}{c}\text { Total } \\
\text { Depth } \\
(\mathrm{ft})\end{array}$ & $\begin{array}{l}\text { Lithology } \\
\text { at Bottom* }\end{array}$ & Township/ \\
& & & \\
Range/Section
\end{tabular}

*Sources of stratigraphy are Tsutsumi and Yeats (1999), Yerkes and Showalter (1990) and Shields (1978). 


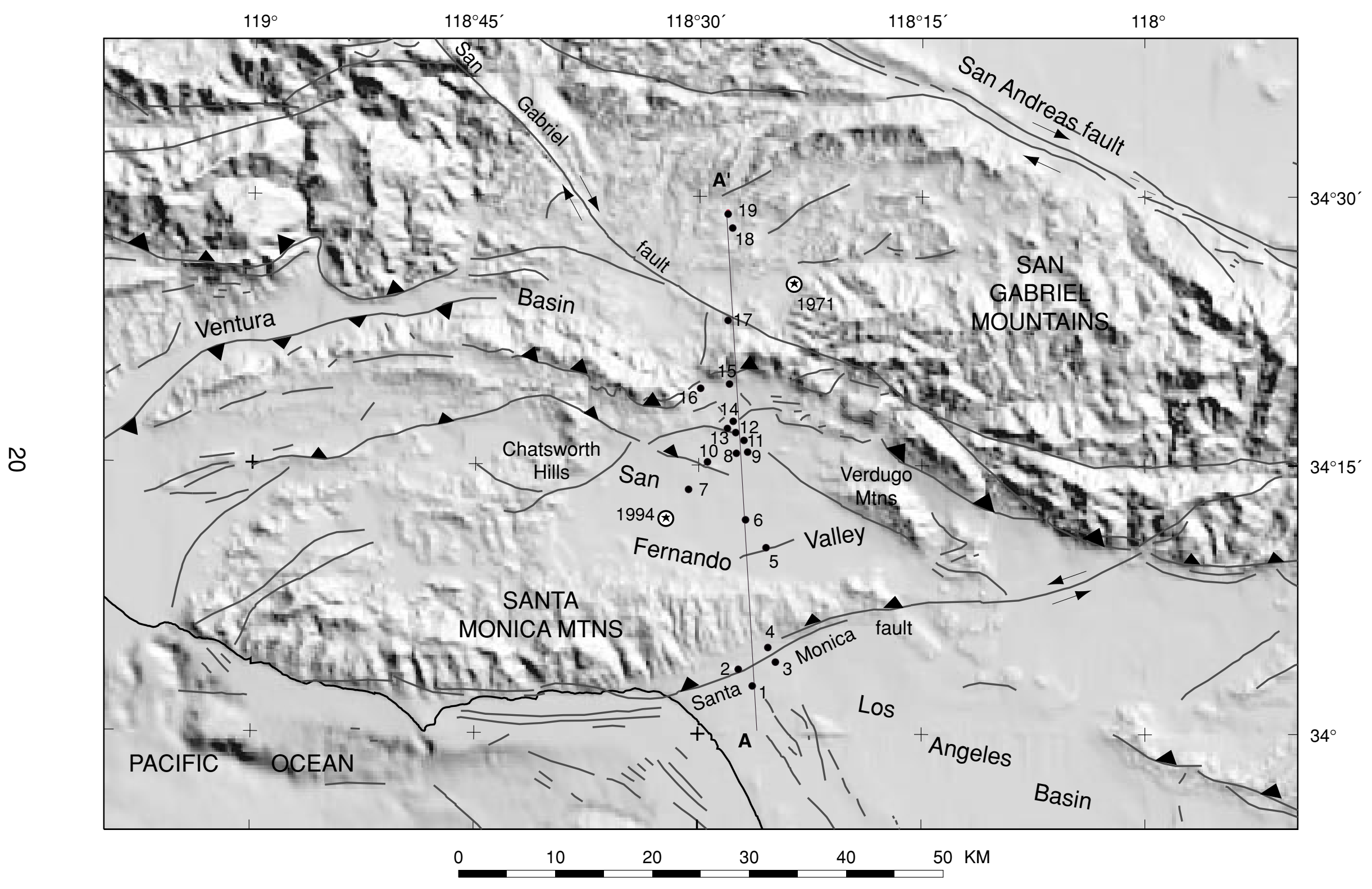

Figure 1. Shaded-relief topographic map of the San Fernando Valley region. Solid circles are selected wells (see Table 1). Stars highlight the 1971 and 1994 mainshock epicenters. Line A-A' is a modeled transect across San Fernando valley. Remaining black lines are faults from Jennings (1994). Teeth denote upthrown side of thrust fault. Arrows indicate sense of strike-slip displacement. 
Paleocene and Miocene sedimentary rocks

v Tertiary volcanic rocks

- Mesozoic sedimentary rocks (including Santa Monica slate)

Plutonic and metamorphic basement rocks

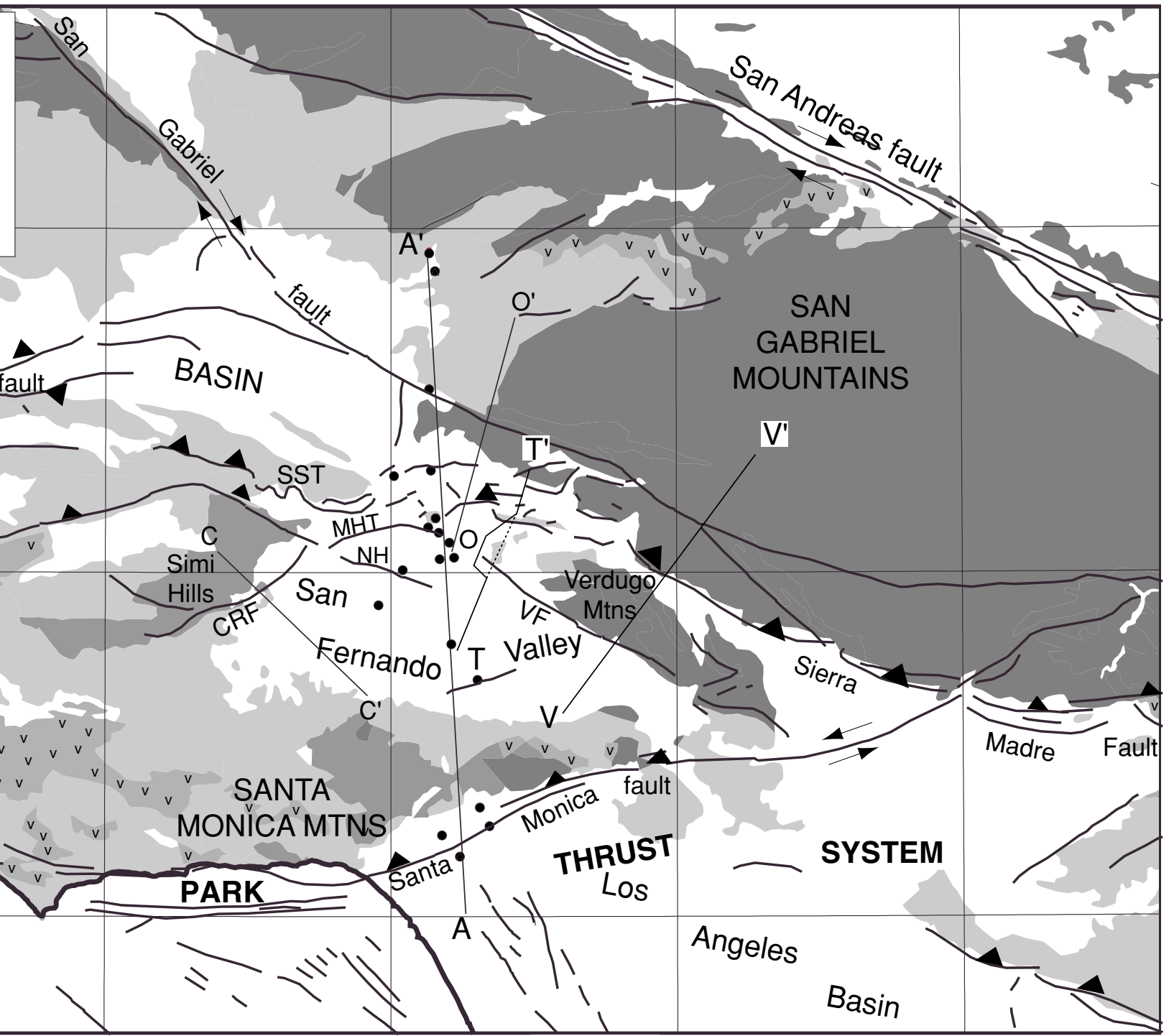

Figure 2. Simplified geologic map of the San Fernando Valley region. Circles are selected wells (see Figure 1 and Table 1). Lines A-A', C-C', O-O', T-T', and V'-V' are profiles discussed in text. CRF, Chatsworth Reservoir fault; MHT, Mission Hills thrust fault; $\mathrm{NH}$, Northridge Hills fault; SST, Santa Susana thrust fault; VF, Verdugo fault. Unshaded areas are Quaternary sediments. 


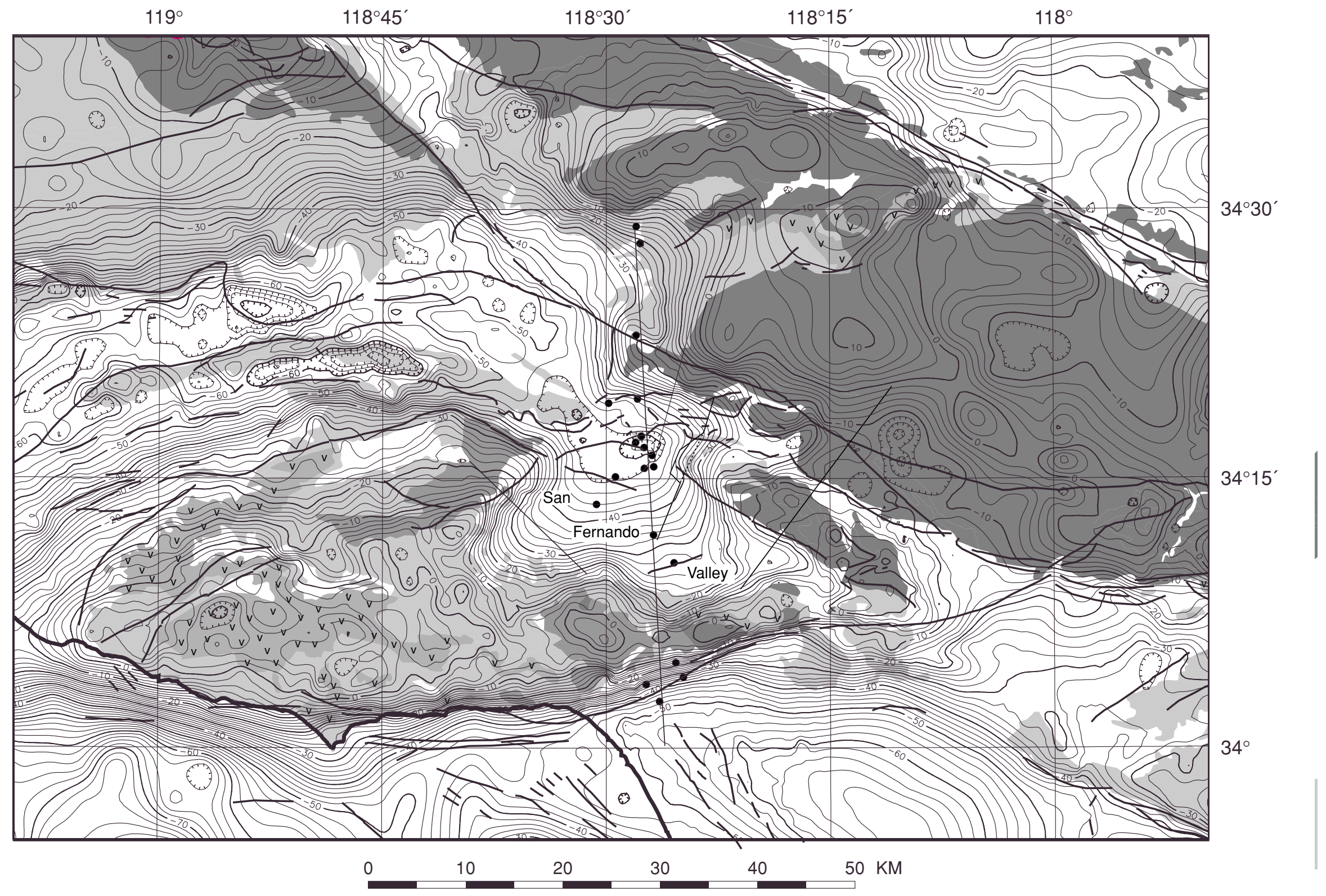

Figure 3. Isostatic gravity map of the San Fernando Valley. See Figure 2 for explanation of simplified geologic base. Contour interval, 2 mGal. Solid circles are wells; see Figure 1 and Table 1 for more information. 


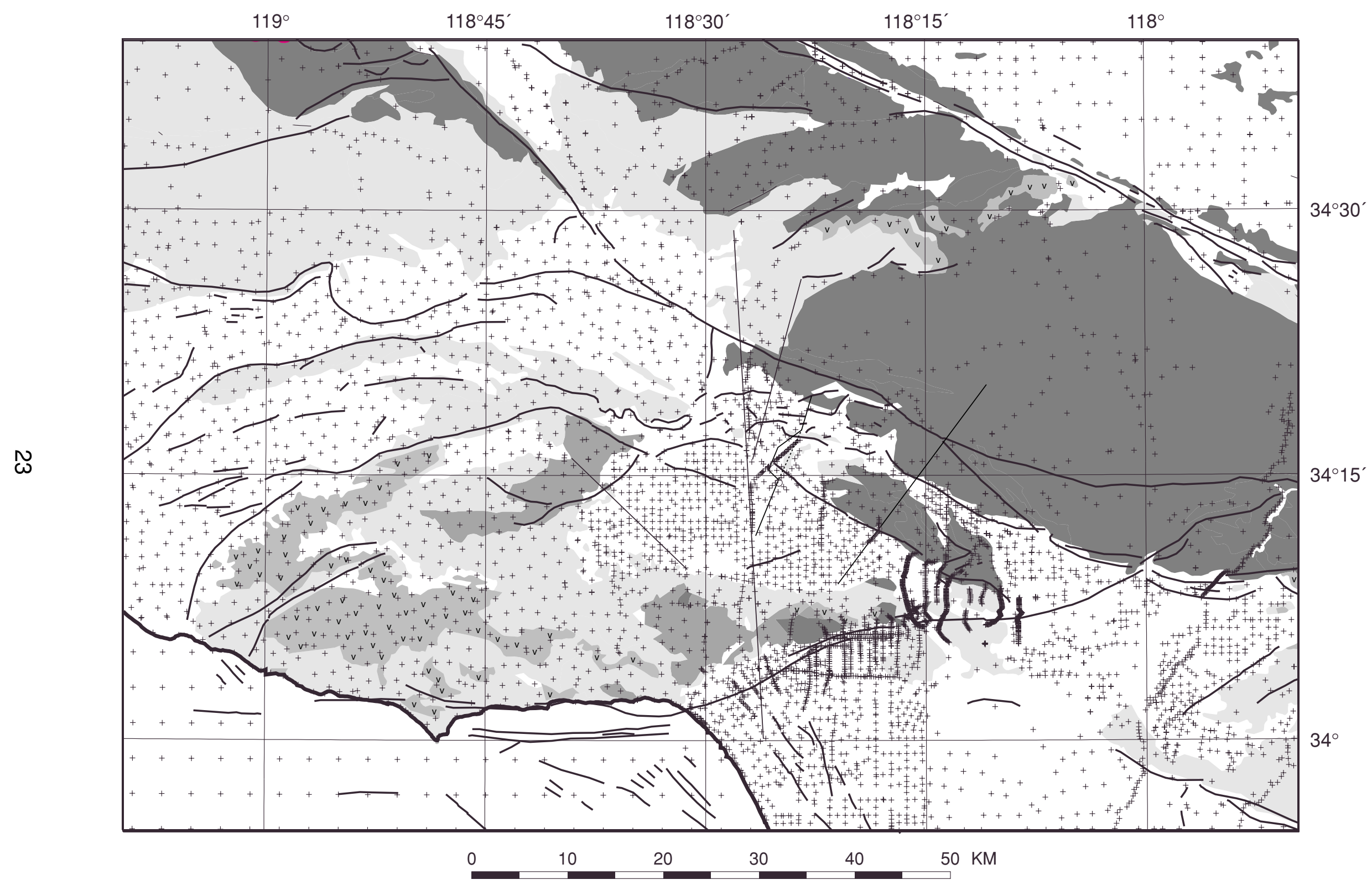

Figure 4. Locations of gravity stations plotted on simplified geologic map (see Figure 2 for explanation of geology). 


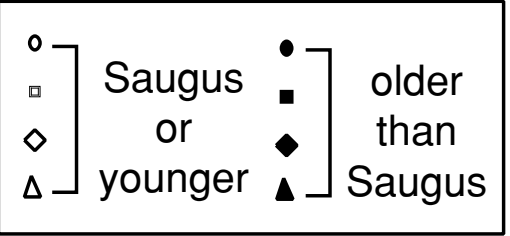

well 15

well 14

well 16

well 10 south of Mission Hills thrust fault

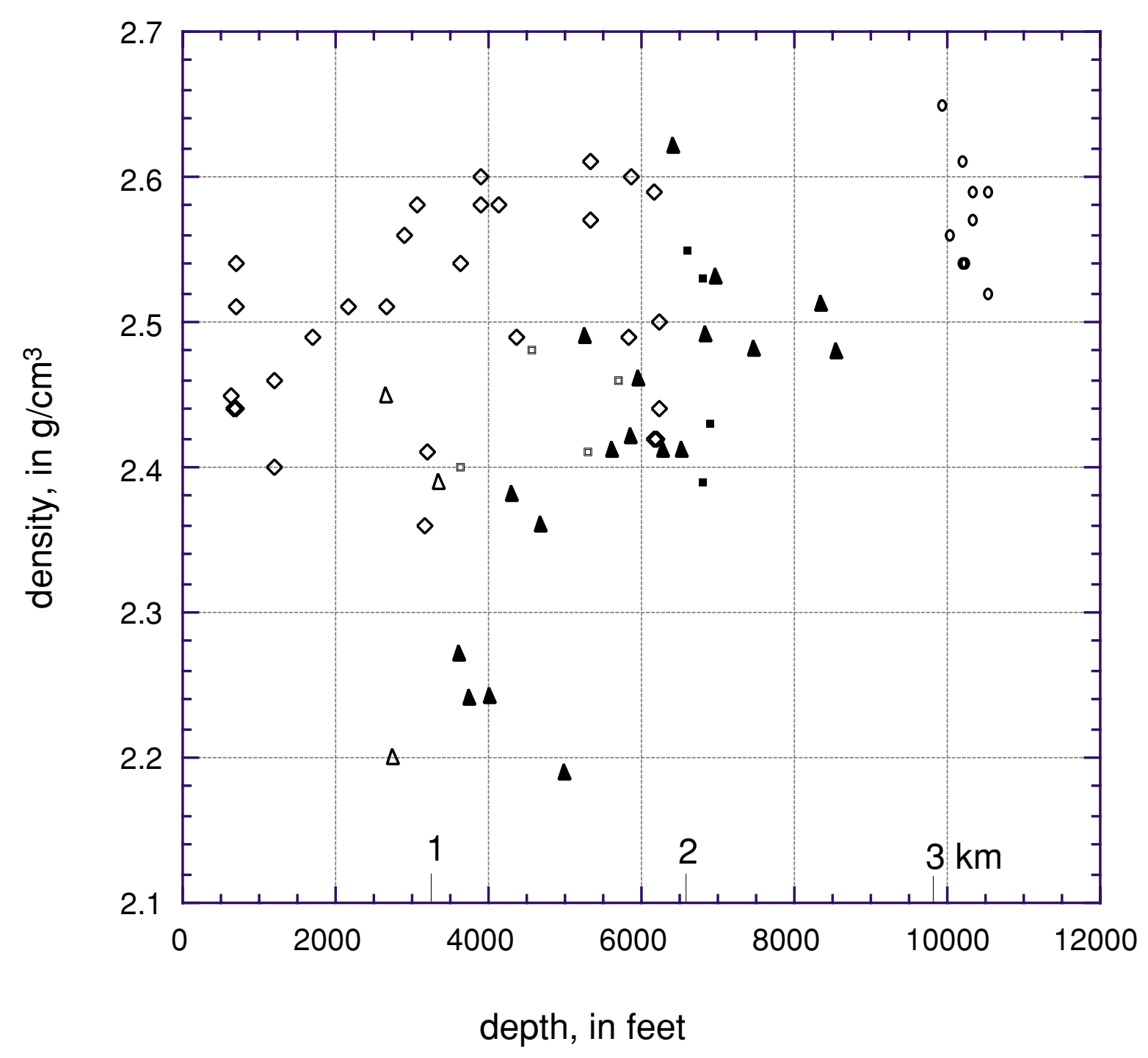

Figure 5. Densities of core samples from Corbato (1963). All core samples are Tertiary or younger sedimentary rocks. Note that densities from the well south of the Mission Hills thrust fault are lower than those measured north of the Mission Hills thrust. 


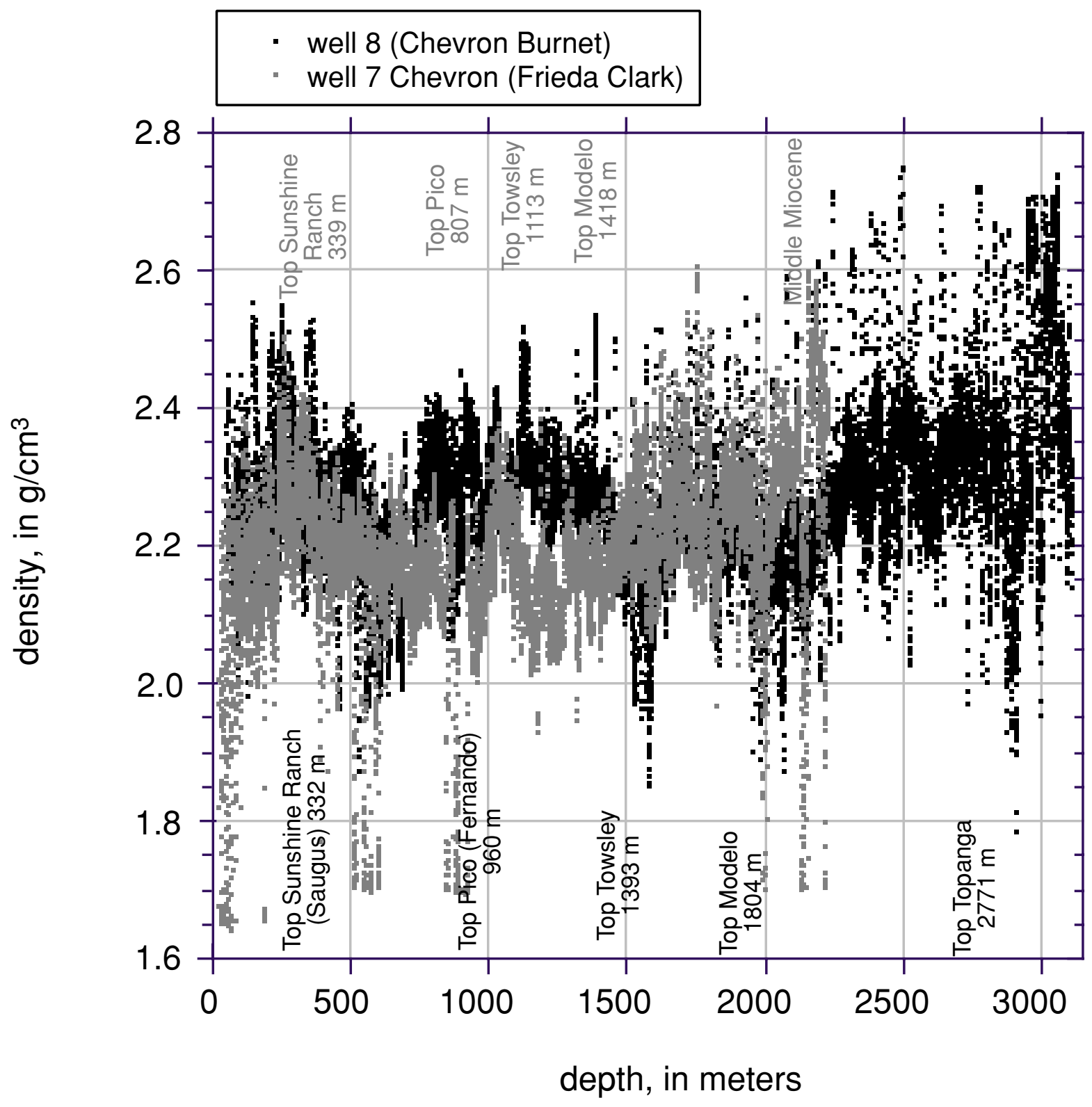

Fig. 6. Density well log information from Brocher and others (1998). Stratigraphic calls for well 7 are shown. 


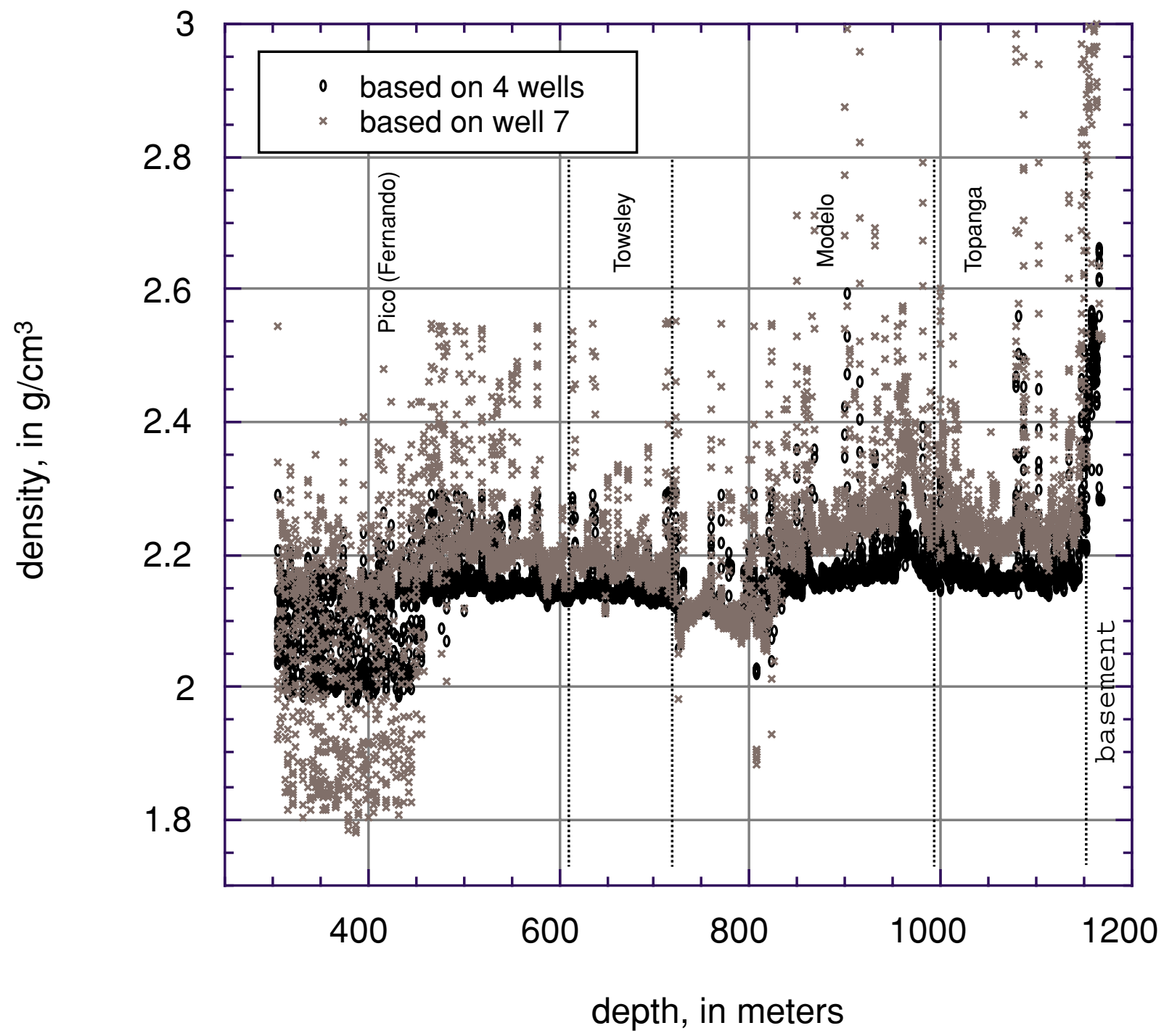

Figure 7a. Densities derived from sonic velocities for well 5 (Chevron Hazeltine). 


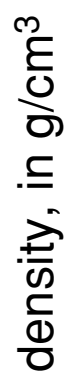

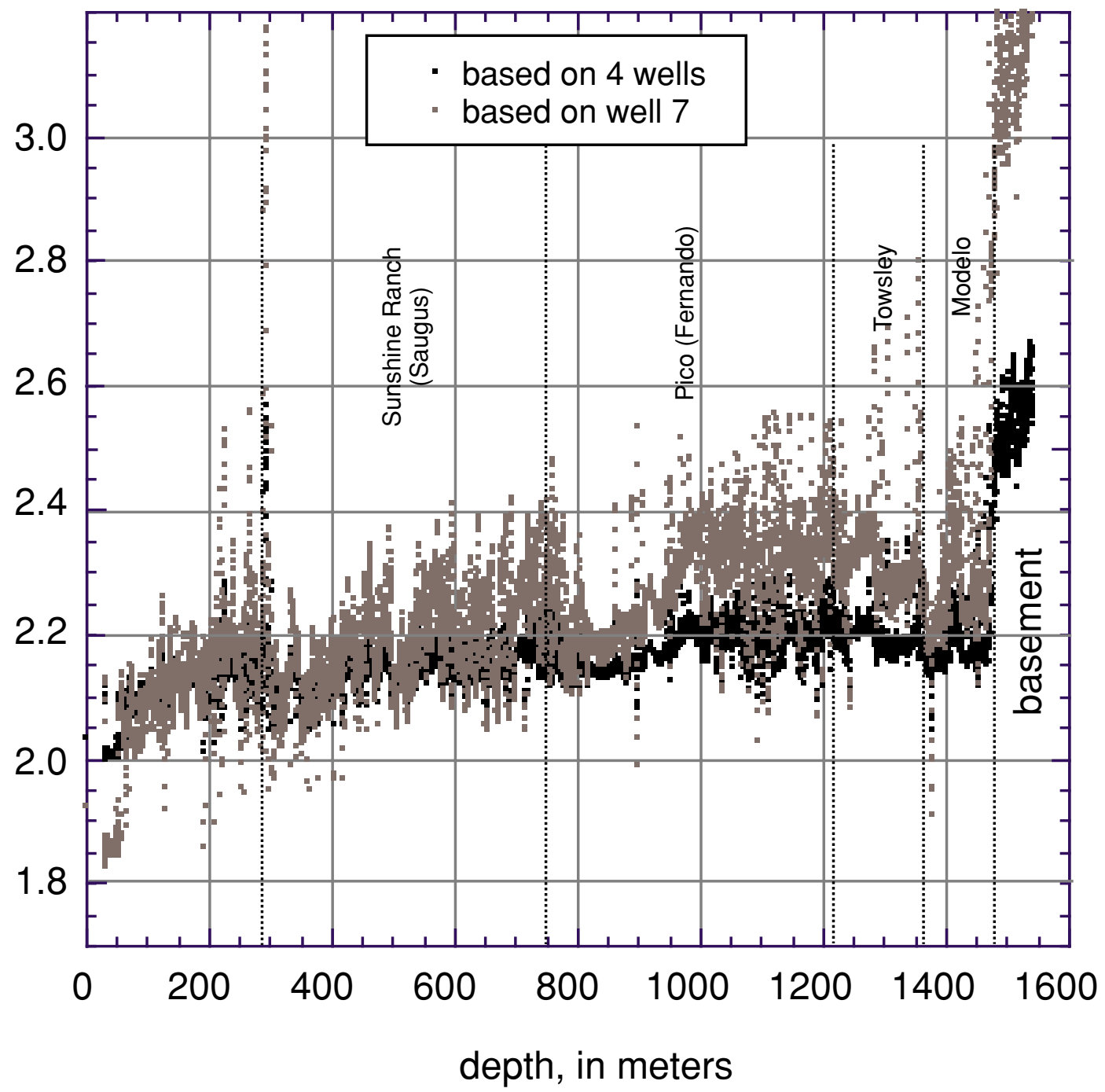

Fig. 7b. Densities derived from sonic velocities for well 6 (Chevron Leadwell). 

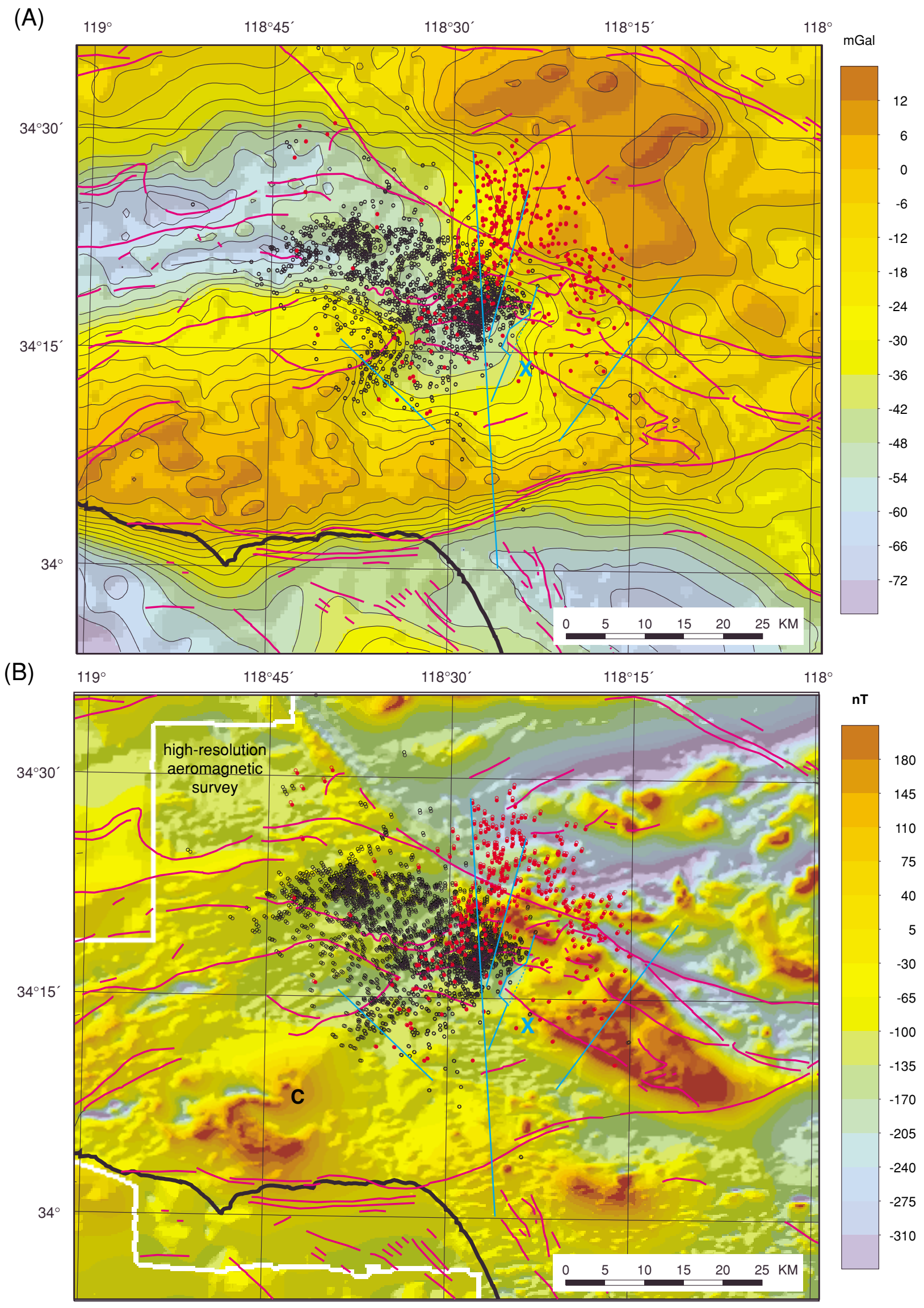

Figure 8. Gravity (A) and aeromagnetic (B) maps with 1994 (black circles) and 1971 (red circles) aftershock seismicity. Some aftershocks appear to be controlled by a northwest-trending structure coinciding with a gravity gradient and with the southeast edge of magnetic block $C$. The blue "X" marks where the geophysical character of the Verdugo fault changes along its strike. Faults are shown in red, blue lines are profiles discussed in text (see Fig. 2). 

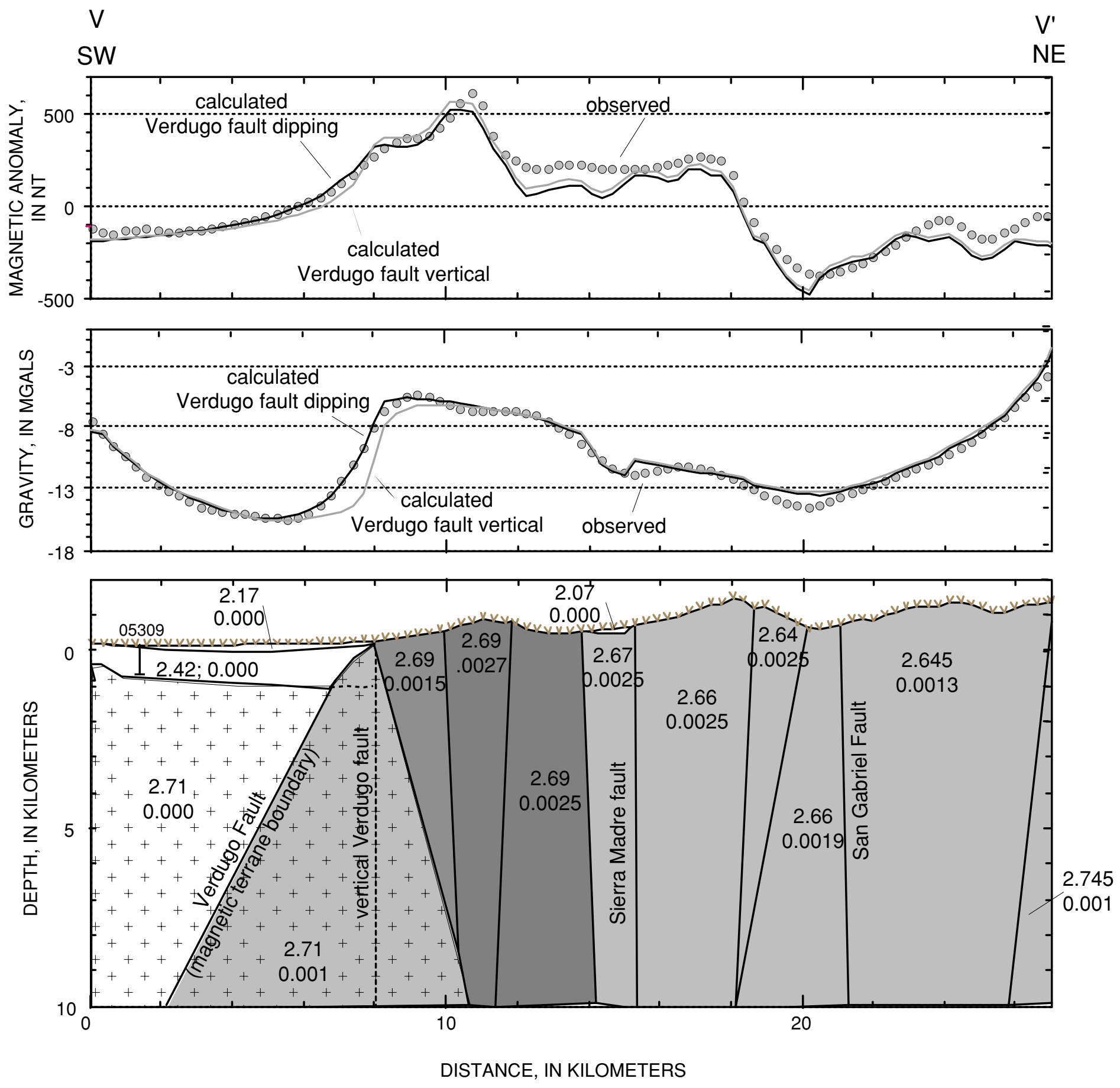

Figure 9a. Gravity and magnetic model across the Verdugo fault (profile V-V' on Figure 2). Numbers are densities in $\mathrm{g} / \mathrm{cm}^{3}$ and susceptibilities in cgs units. No vertical exaggeration. Sources extend to $10 \mathrm{~km}$. The calculated gravity curve matches the observed gravity data if the Verdugo fault dips to the southwest. A dipping fault also matches the gentle decrease in magnetic values southwest of the fault better than if the Verdugo fault is vertical. Geometries of the San Gabriel and Sierra Madre faults are poorly constrained by the gravity data because of sparse gravity coverage along the profile (Fig. 4). 

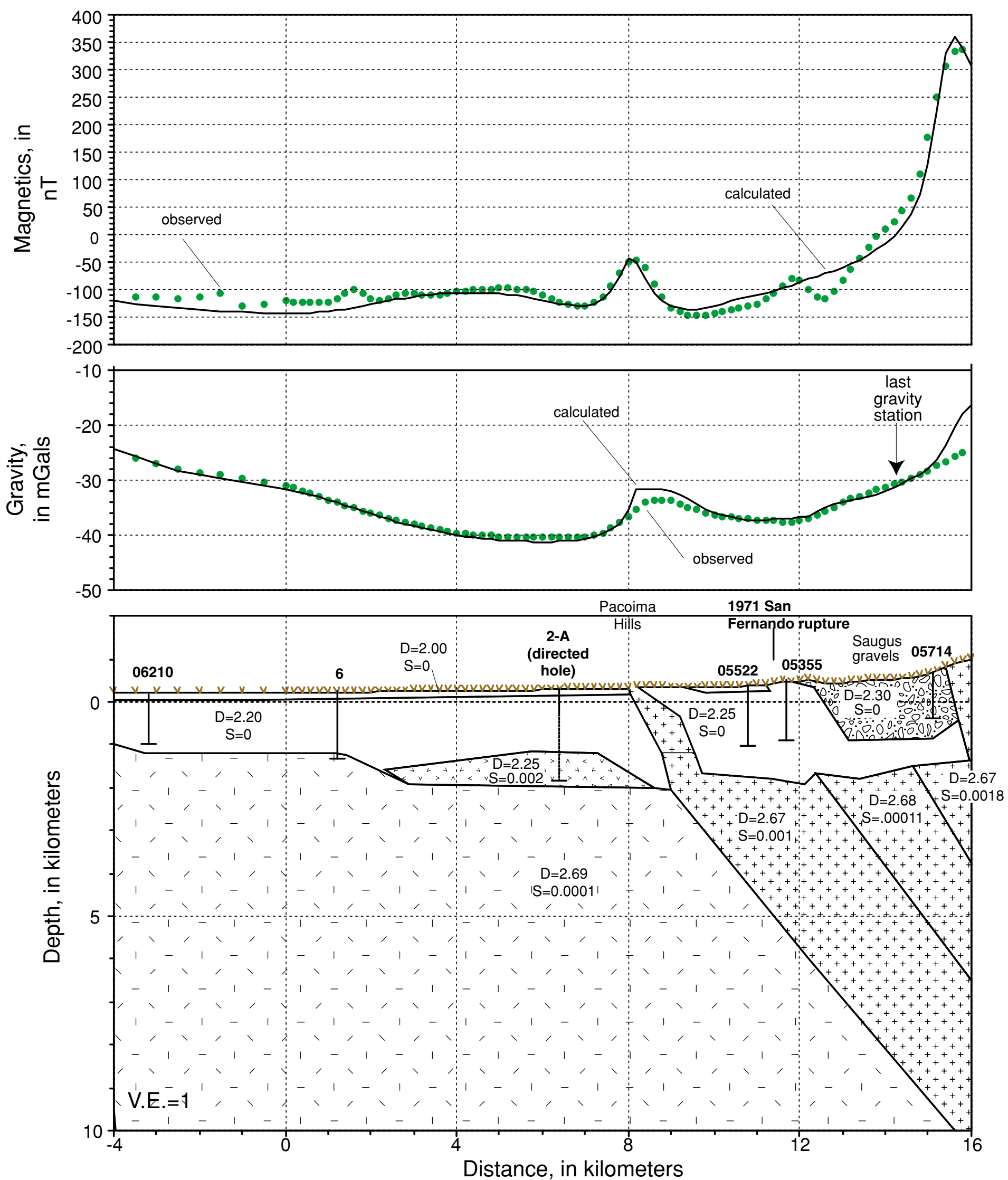

Figure 9b. Gravity and aeromagnetic model across T-T' (straight line). Data points are gridded values and are poorly constrained at the far northeastern end. Numbers above wells refer to wells in Tables 1 and 3. 


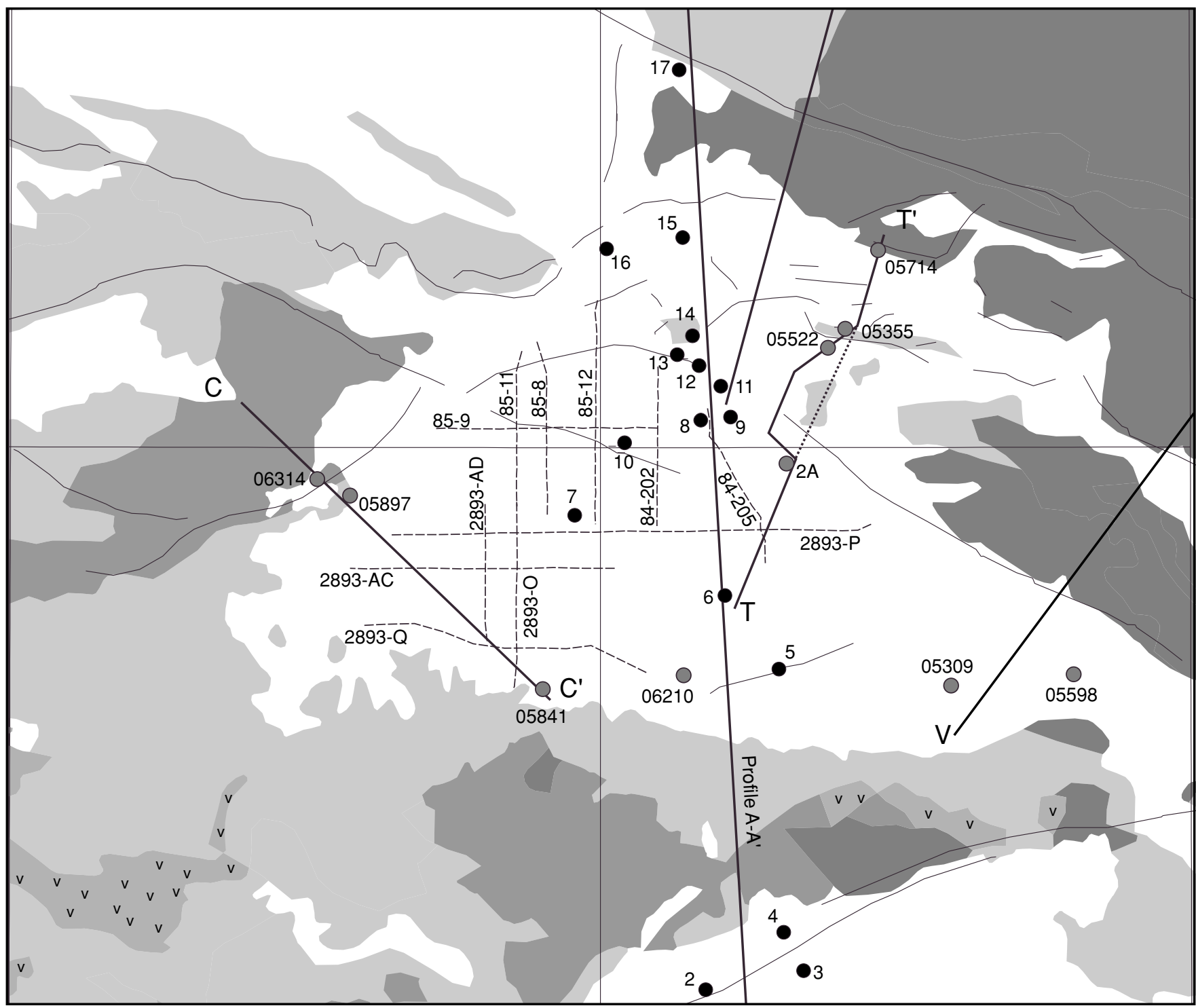

$341^{\prime}$

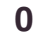

10

$20 \mathrm{KM}$

Figure 10a. Map showing locations of additional wells and seismic-reflection profiles. Solid black circles are wells listed in Table 1; gray circles are listed in Table 3. Dashed lines are seismicreflection profiles. 

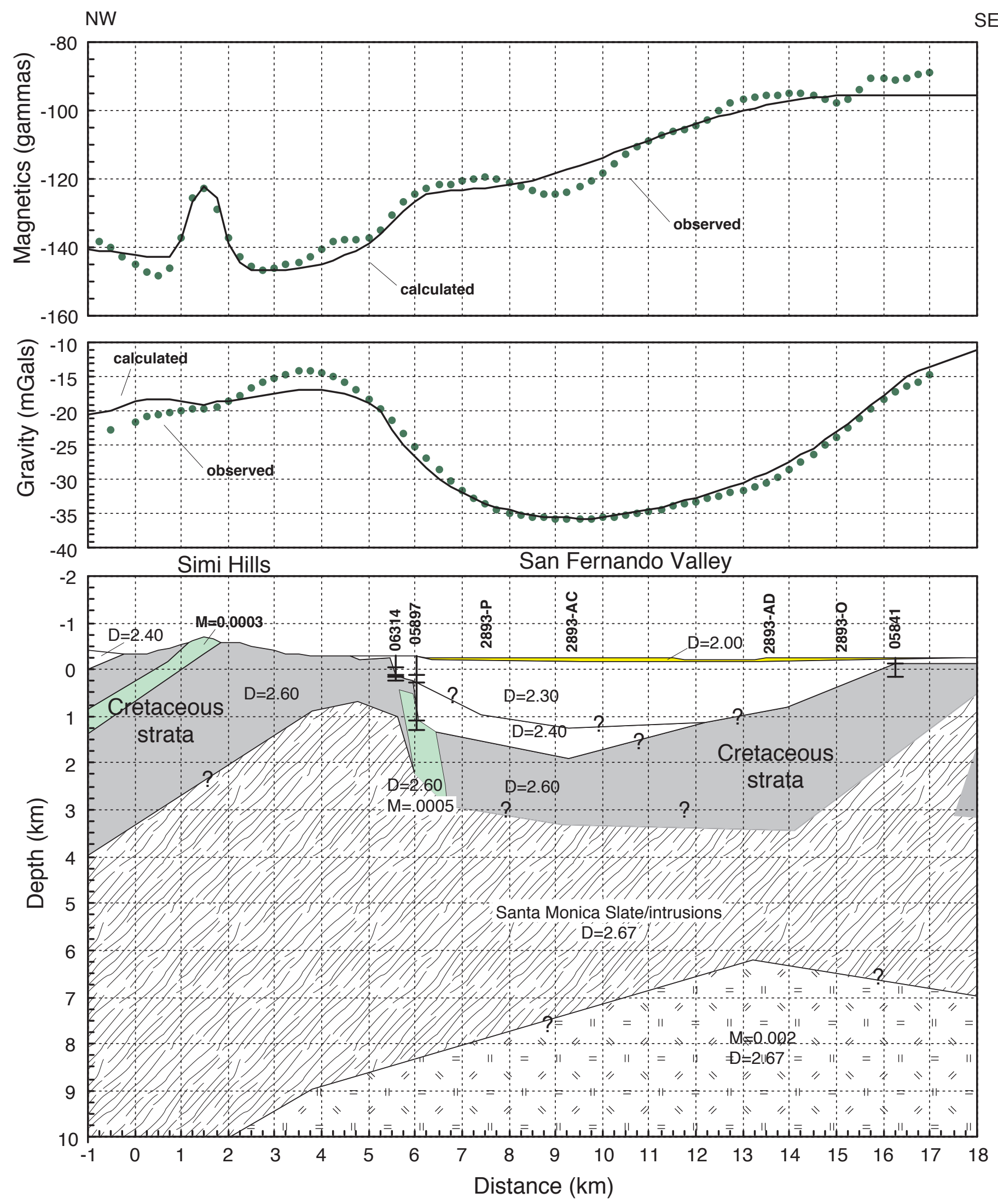

Figure 10b. Gravity and aeromagnetic model across the northwestern margin of San Fernando Valley. Numbers on bodies refer to densities (D) in $\mathrm{g} / \mathrm{cm}^{3}$ and magnetic susceptibilities (S) in cgs units. No vertical exaggeration. 

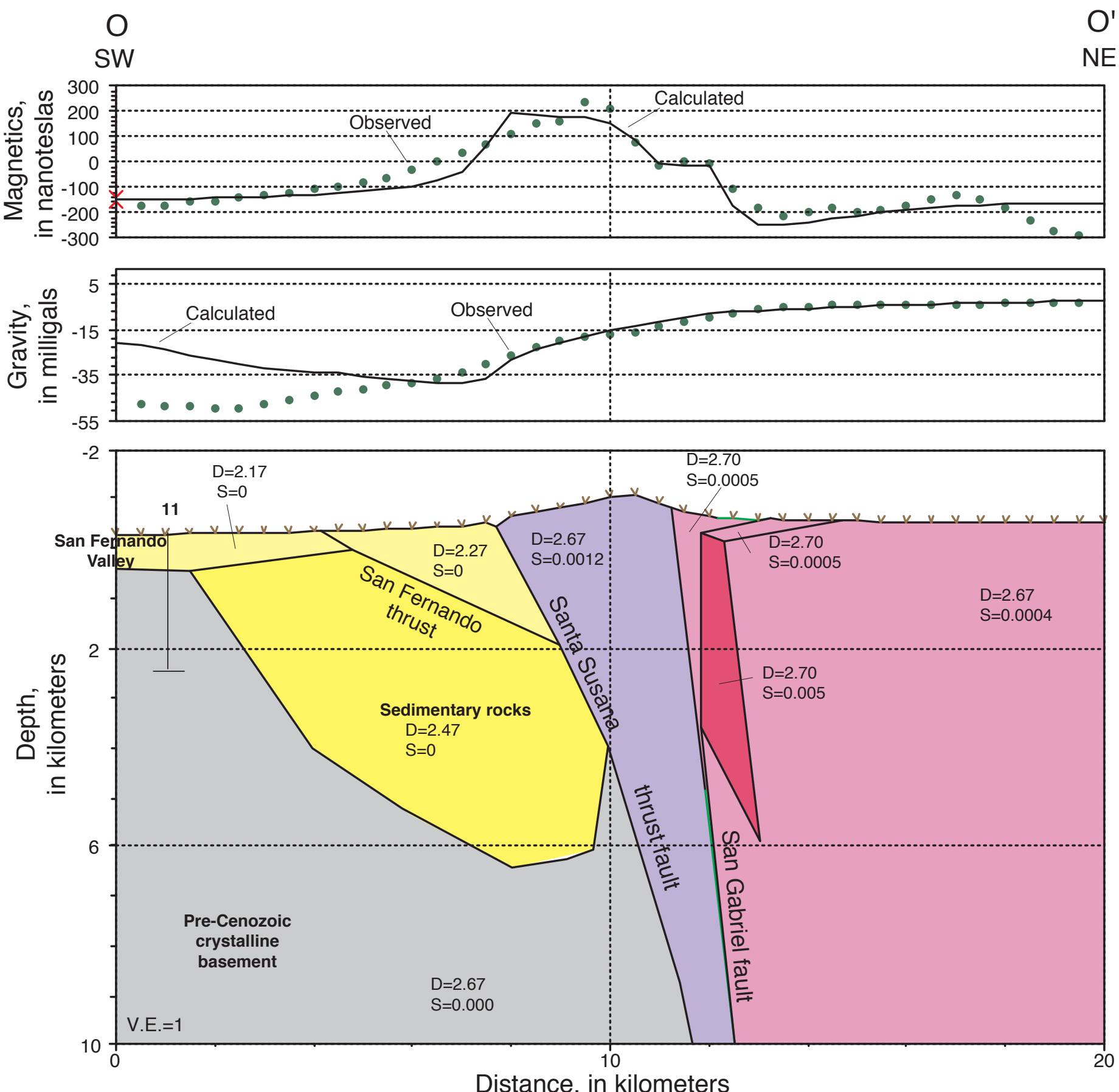

Figure 11. Gravity and magnetic model of Oakeshott (1975b) cross-section O-O'. Densities are in $\mathrm{g} / \mathrm{cm}^{3}$;susceptibilities are in cgs units. Note mismatch between the calculated and observed gravity values at the southwest end of the model. Thus, the basin must be deeper to account for the gravity low on the southwestern part of the profile. Well 11, which bottomed in Miocene, (Table 1) confirms this conclusion. 

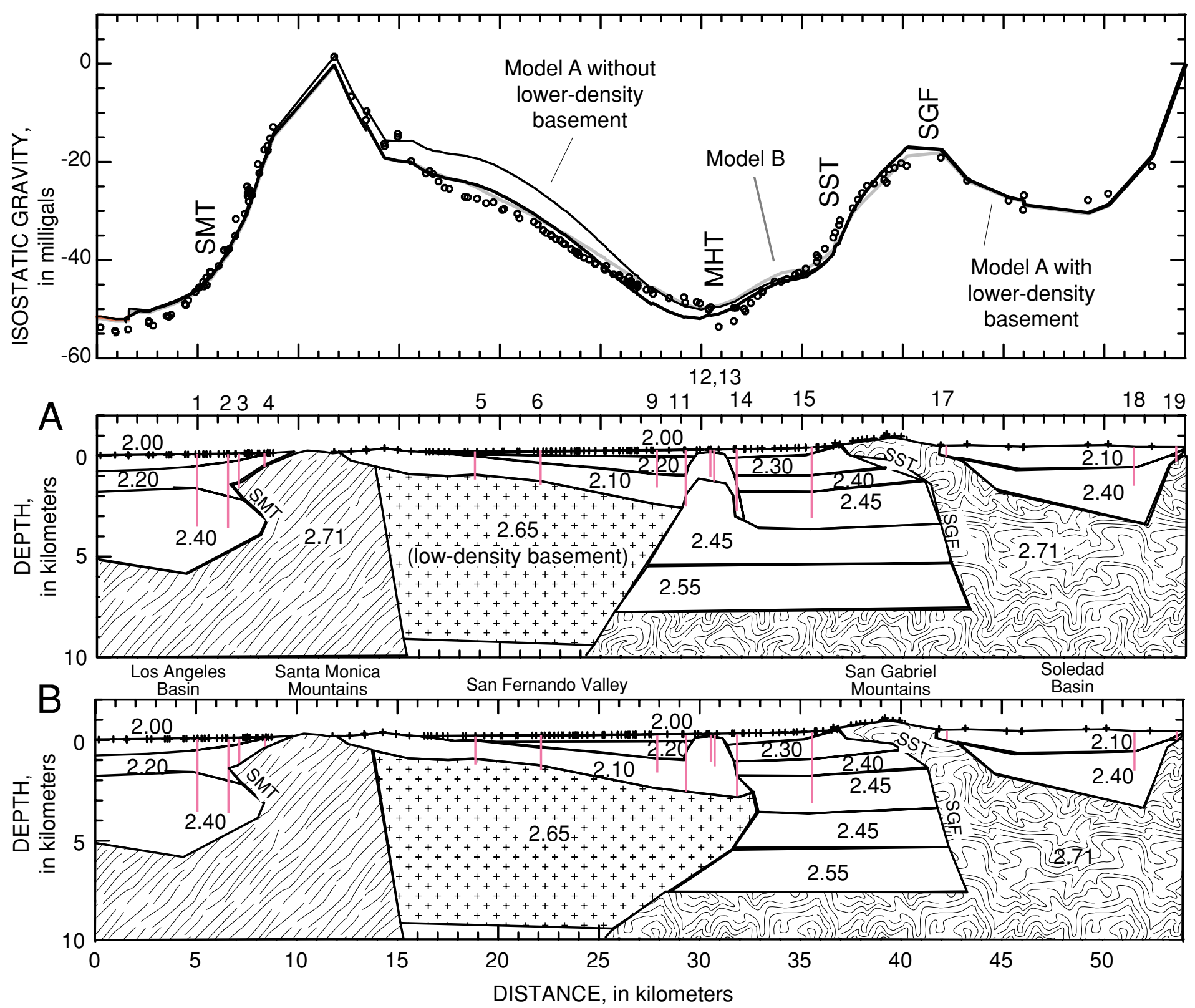

Figure 12. Gravity models across the San Fernando basin along profile A-A'. Small crosses on models are gravity station locations. Numbers in model are densities in $\mathrm{g} / \mathrm{cm}^{3}$. Numbers above the model panel A refer to wells shown in Figure 1 and described in Table 1. MHT, Mission Hills thrust fault; SGF, San Gabriel fault; SMT, Santa Monica thrust fault; SST, Santa Susana thrust fault. 
(A)

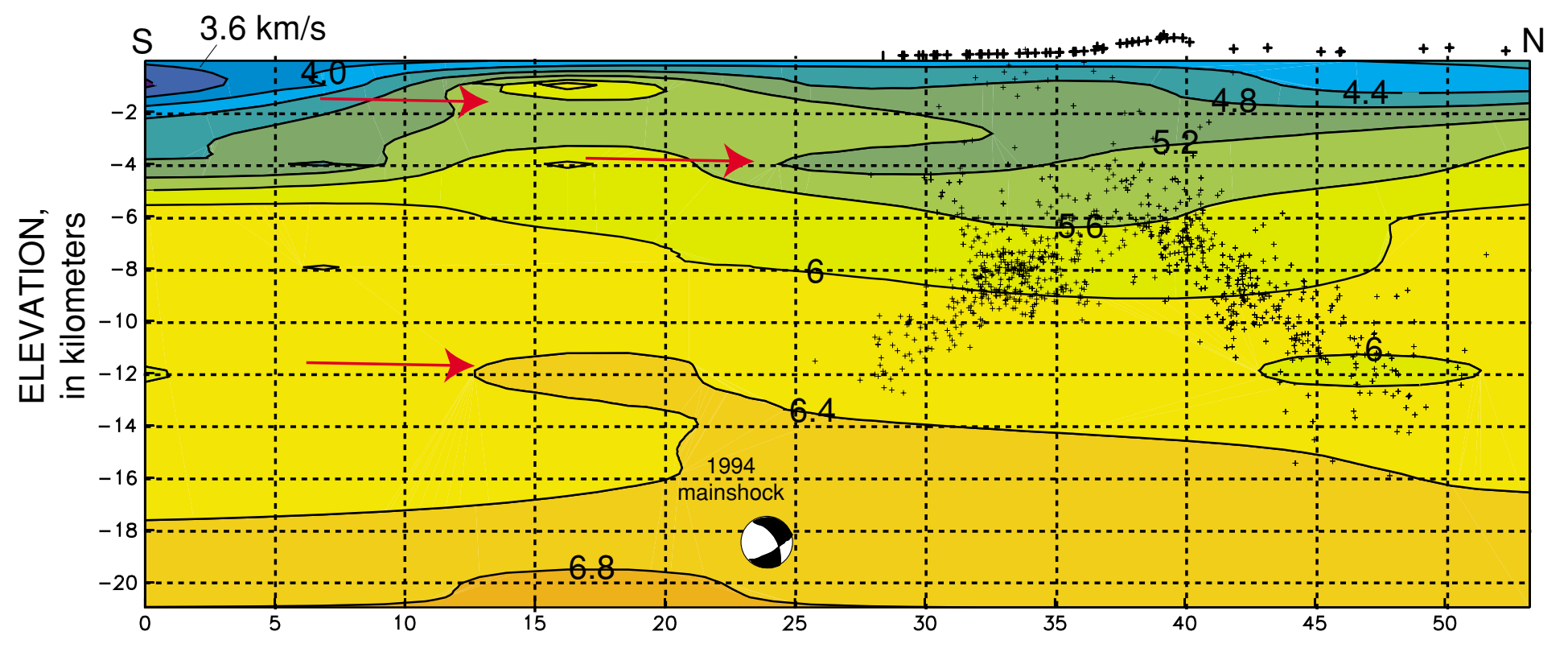

(B)

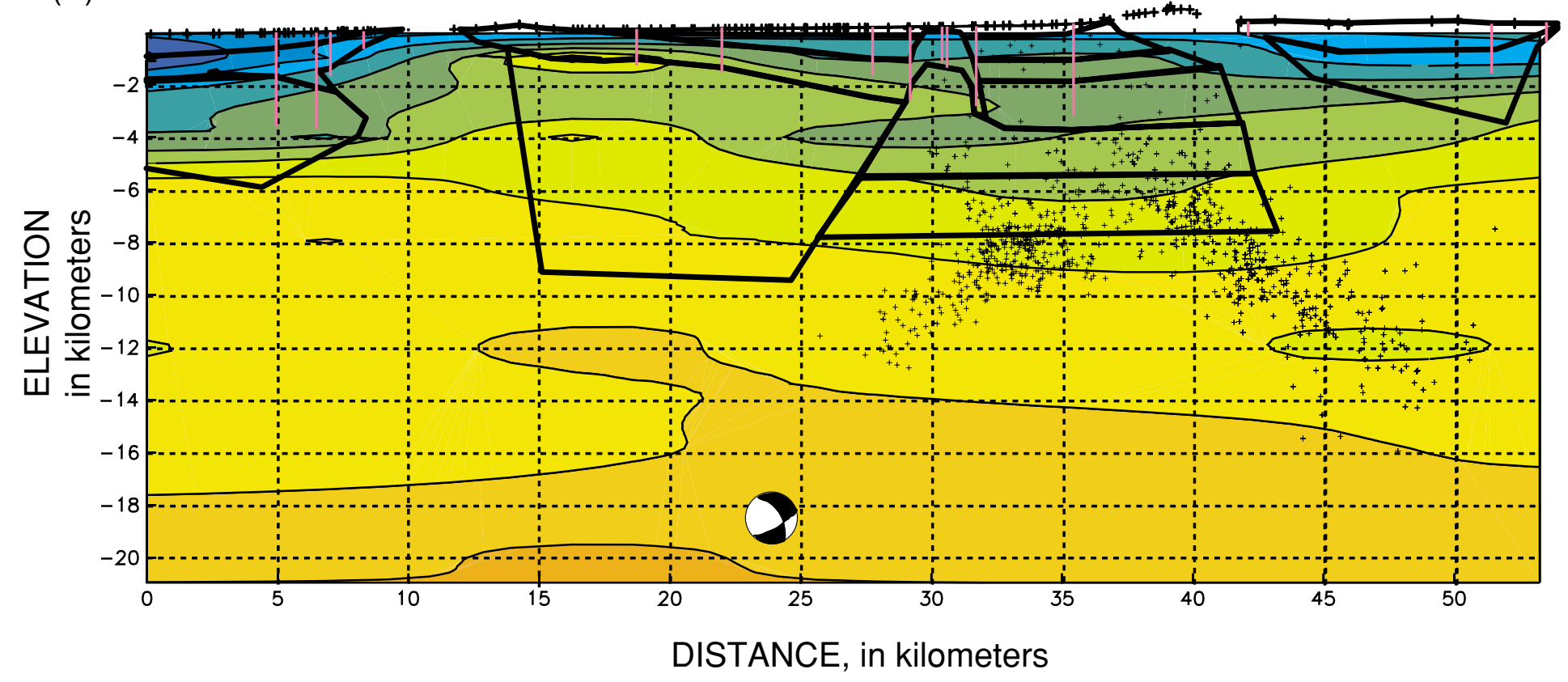

Figure 13. (A) P-velocity across A-A' from Hauksson and Haase (1997). Units are in $\mathrm{km} / \mathrm{s}$. Small crosses, 1994 and 1971 aftershock seismicity. All aftershocks within $2 \mathrm{~km}$ of A-A' were projected onto profile. Red arrows point to possible artifacts caused by single wavepath smearing. (B) P-velocity with superimposed gravity model. 


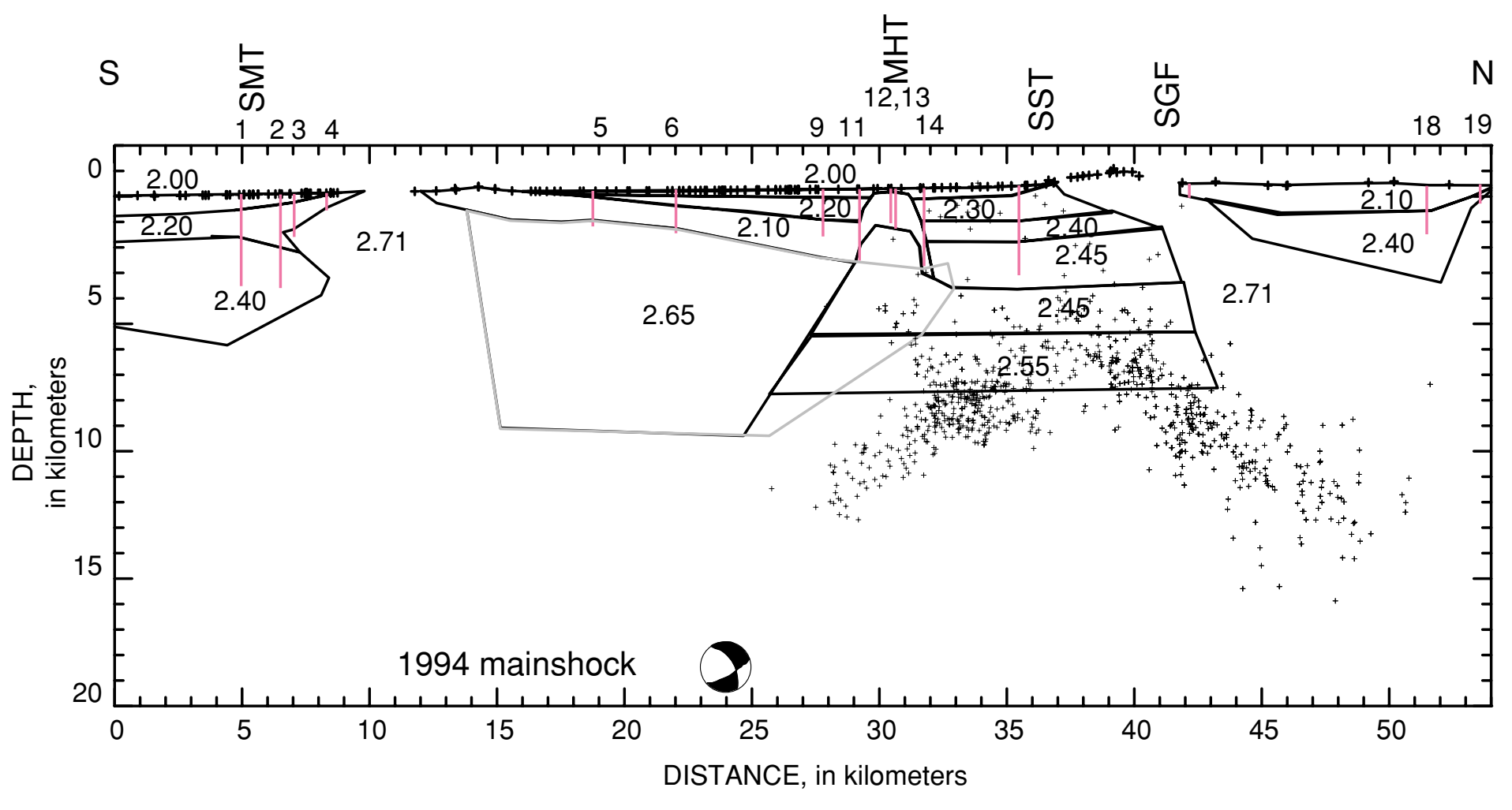

Figure 14. Gravity model with 1971 and 1994 seismicity (small crosses) projected onto profile A-A'. Gray outline shows basement geometry from model B.
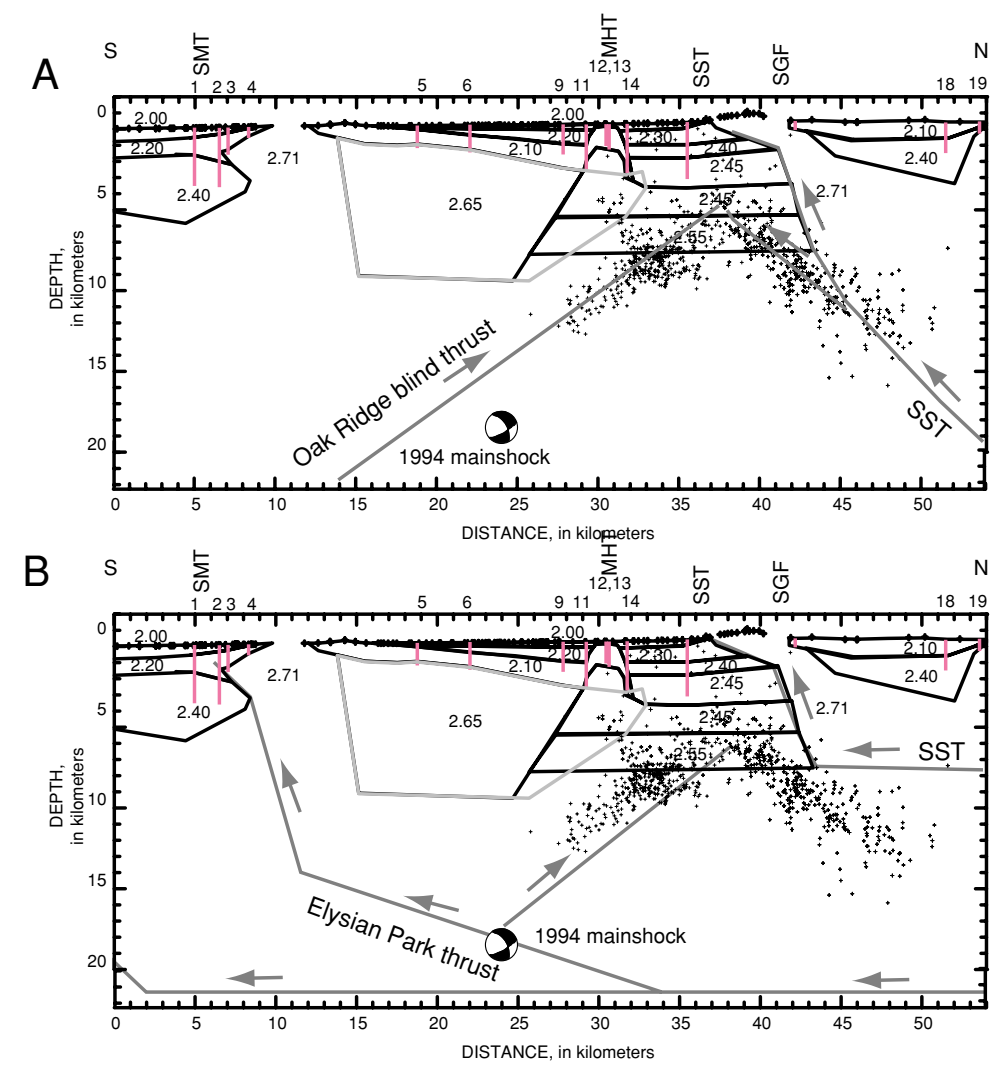

Figure 15. Structural models for the Northridge earthquake superimposed on gravity model.

(A) Model taken from Yeats and Huftile (1995) where the Northridge thrust occurred along the continuation of the Oak Ridge thrust fault.

(B) Model from Namson and Davis (1994) where the Northridge earthquake occurred along a back-thrust of the Elysian Park thrust fault. SST, Santa Susana thrust fault. The gravity models can be used to support either interpretation. 